\title{
The genres of the Nenets songs
}

\section{The Nenets}

The Nenets are the largest ethnic group among the speakers of the Samoyedic languages. According to the 1990 statistics they numbered up to 34.190 persons, of whom those, who spoke Nenets as a primary language, averaged to $82 \%$ (Janhunen 1990) ${ }^{1}$.

By their language and their culture, the Nenets form a surprisingly uniform group without any major dialects or cultural units deviating heavily from the whole, except a small group called Forest Nenets or Nyesha".

Thus their future on the level of cultural continuity seems much more favourable than that of many other Siberian arctic or subarctic indigenous people, including for example the Sami of Northern Scandinavia. On the other hand, there is a clear division between those who still continue with their pastoral reindeer economy in tundra areas, and those who gather in polyethnic villages and population centers. The reindeer herders of the tundra have fewer problems in continuing their traditional way of life, than their sedentarized kinsmen, who acculturate more rapidly to their neighbours (of whom a dominant part are Russians and Ukrainians). It must be said, though, that the last "free" reindeer pastoralists do not represent a cultural isolate in Northern Eurasia and Western Siberia. They all are to some extent dependent on the adjacent economical systems (primarily the state economy, which provides products of industrial technology and agriculture by trade).

In addition, it is important to emphasize that irrespective of the relatively good future prospects concerning their culture and language, they are an ethnic minority in their own land. Perhaps it is not so true on the sparsely populated tundra, but it is especially so in villages and towns. Also the last habitations of the pastoralists of the tundra face considerable changes: they happen to be located in the neigbourhood of rich oil and gas deposits (e.g., in the Kara Sea and Yamal Peninsula).

The Nenets language belongs to the Samoyedic branch of the Uralic languages (the other branch being the Finno-Ugrian) ${ }^{2}$. The main dialectal division is made between the Tundra Nenets (a 95\% majority) and the Forest Nenets. Notwithstanding the immense area inhabited by the Tundra Nenets, their dialectal differences are minimal. However, Forest Nenets differs from Tundra Nenets as sharply as for example German from Dutch, beyond the level of mutual understanding. The Nenets literary

\footnotetext{
${ }^{1}$ According to Russian statistics, the population rate is 34.665 , of which $77.1 \%$ speak Nenets and $18.1 \%$ Russian as primary language, and $61.7 \%$ Russian as secondary language and $35.3 \%$ don't master any secondary language (Anonymous 1990). See also Salminen's (1997) account about the Nenets language. ${ }^{2}$ It is nowadays regarded as correct not to refer to the Uralic language family, containing Finno-Ugrian and Samoyedic branches, but simply to speak about Finno-Ugrian language family, containing Samoyedic branch (cf. Salminen 1997).
} 
language was established in 1930 ' $\mathrm{s}^{3}$.

The former appellation of the Nenets was "Yurak Samoyed». Their present appellation, the "Nenets", which is what they call themselves, was established in Soviet time, along with similar practices among the other indigenous peoples of Siberia.

The Nenets inhabit an immense tundra- and forest-tundra-zone from the Kanin Peninsula in the European side to the Taimyr Peninsula in the Siberian side of the Russian North. Formerly they inhabited also some of the major islands in Barents and Kara Sea, like Novaya Zemlya, from which they were forced out by the government, once it became a nuclear base.

The major subgroups of the Tundra Nenets are 1) the Western (or European) Nenets to the West of the Ural mountains, 2) the $\mathrm{Ob}$ and Yamal Peninsula Nenets and 3) the Yenisey and Taimyr Peninsula Nenets. The Forest Nenets inhabit mainly the Pur river and some of the according northern tributaries of the Middle $\mathrm{Ob}$.

The present Nenets are mainly reindeer herders, hunters and fishermen. Before adapting the techniques of herding the semi-domestic reindeer, they were mainly hunters of the wild reindeer. This means that the reindeer - either wild or domestic represents one of the elementary subsistence patterns in their culture, reflecting substantially as well in the material culture as in the symbolic culture. The reindeer is the raw-material source of food, clothing, household tools and transport. It is the main unit of social status and wealth.

The Nenets adopted a nomadic form of reindeer pastoralism. It means that a household (especially before: of the same family) transhumances along with the annual migration routes of their reindeer stock, thus herding it a year round. The traditional type of dwelling, a conical hut (mya") is ideal for the mobile migratory way of life. ${ }^{4}$ During the Soviet time the reindeer economy was reorganized into the kolkhoz/sovkhoz system. This system still exists and it means, that the majority of the reindeer-herders work in some of the state "farms". While the farms have a village as their center, this means, that most of the reindeer-herders live in villages and mostly their families are stationed in the villages, while the herders work periodically (for example two weeks) with the reindeers in the tundra as shift-workers. The principle of the state farms has been that of maximizing the population of the reindeer herds for the sake of production. This has caused problems of overgrazing, big herds spoil the ground and potential epidemics are much more disastrous.

\footnotetext{
${ }^{3}$ The Nenets terms presented in this article are Latinized from the Nenets literary forms (written in Cyrillic). As such they are only approximations of the original phonetic forms. In this Latinization, the ascending accent mark () over a vowel indicates length and he apostrophes ' and " stand for laryngal stops (cf. Cockney «bottle $=$ bo'l»). Nasal nn $^{\prime}$ is written as ng. It is a sound that can occur also in the beginning of a word in Nenets. A "X» stands for a slightly fricative h. In addition to its normal usage in English, letter "y" stands for palatalization of the former consonant (e.g., tádyebya). If not preceded by palatalized consonant, letter «i» stands for middle-i and letter «e» for a sound in between of e and æ (cf. English «hat»). In addition, the Forest Nenets voiceless $\alpha$ l $w$ is written here with an uppercase "Lw. As an exception to these rules, I have latinized the Nenets names with more straight correspondence to their Cyrillic forms.

${ }^{4}$ A rather comprehensive monograph on the Nenets is made by a Russian ethnographer Lyudmila Vasil'evna Khomich (1966).
} 


\section{The genres of the Nenets songs}

Usually the Nenets songs are divided into "epic", "lyric" and "ritual (i.e. shamanistic)" songs, according to the traditional tripartite view in folklore studies (cf. Kupriyanova $1960,17-19 ; 1965$, 19; Khomich 1966, 315). This analytical division is based on the characteristics of the thematic and structural features in the contents of the song texts. While this division can be broadly applied as an overview of the Nenets song culture, it has some problems, discussed below.

It has to be noted, that Kupriyanova does not discuss her use of the concept of "genre". She only presents them a priori (cf. Kupriyanova 1965, 20). On the other hand she refers to the song genres mainly with the concepts of "type" or "term". Later, however, for example Pushkarëva ${ }^{5}$ for example differentiates in her folklore research the characteristics of scientific-analytic conceptualization of genres from that of intracultural conceptualization, and their applications among different researchers (Pushkarëva 1990, 81-82).

As such, the implicit views of the Russian scholars about the definition of the concept of genre can be seen as converging with the views of folklore studies in the beginning of our century. Genres were thought as ideal types, which existed categorically, and which were not subject to changes. The living traditions had to be fitted to these categories. The origins of this kind of thinking can be traced to Linnaean views in the natural sciences. On the other hand, the main purpose of this kind of thinking was classification for purposes of organizing and archiving the documented materials. (cf. Ben-Amos 1981, xv-xvi)

In other respects, however, the views of the Russian scholars reflect also evolutionist concepts of genre in human oral culture. While the genres were seen as existing as cultural entities, and representing a categorical stability in the tradition as a whole, their contents were subject to change. This was thought to happen by the transfer of the themes of culturally crucial genres to the more marginal genres. (For example when a myth becomes obsolete, its content may continue its life in children's songs, riddles etc.) On the other hand, a genre could disappear from usage by loss of its social relevance. (cf. Ben-Amos 1981, xxi)

The traditional genre analysis in folklore studies has its point of departure in oral texts, which were seen as unchanging once they were documented. The genre distinctions were seen to emerge from the characteristics of textual content, like the structural features of the theme and content. This situation lasted surprisingly long in folkloristics, as pointed out already by Honko (1967, 3-6). The discussion of the ontological status of the folklore genres is also worth noticing here. Are the genres the analyst discerns, conceptualizes and analyzes fundamentally assumed to be real or only ideal types? This vigorous but inconclusive controversy between conceptual realism and nominalism does not require detailed discussion here. Honko (ibid., 20) has proposed that the solution to this discussion lies in the way the empirical data and the theoretical framework can be put into a fruitful relationship with each other. In other words, the realistic and the nominal conceptualization should not necessarily be regarded as mutually exclusive.

With the Nenets material, for example, I was interested from the beginning to see what kinds of organizational principles - converging or contrasting - there are between

\footnotetext{
${ }^{5}$ Elena Timofeevna Pushkarëva (née Lapsui) is herself a Nenets by nationality.
} 
the emic terminology and the genre categories formulated and applied by scholars. In addition, the fundamental assumptions regarding terminology used in the analytical conceptualization, have been extensively discussed in folklore studies beginning with the Grimm brothers (cf. Dundes 1980, 38). According to Honko (1967, 12-16), Bascom $^{6}$ refers to three basic criteria, with which it is possible to organize a corpus of oral narratives. The first consideration is the form of the text, whether it is uttered in prose or verse form. Second is the definition of the truth status, whether the performer/audience believes the tale to be true or not. Third, the time of the events in the narration should be considered: whether they happened in the mythical or historically definable past, or whether it is irrelevant to date them. While studying songs, it is worth noticing that the sung text is sometimes a specialized form in itself, suggesting distinctions between genres or subgenres (as in the Nenets laxanako ('fairy tale') compared with syosawei laxanako ('sung fairy tale')). This way, in the study of a song culture, it becomes relevant to distinguish between texts performed in prose narration, verse form narration or sung verse form narration. Theoretically, also a "sung prosaic narration" could also be possible, but there appear to be no actual examples of this, at least in the Nenets material. Perhaps the (partially improvised) drinking songs (see below) come closest to that, but the relationship between singing and the verse form text is so deeply entrenched, that the singer, even improvising in a drunk state, tries to express him/herself in verse form as best as (s)he can.

In itself, the criteria according to which the analyst forms the generic concepts, should manifest some kind of uniformity. Let it be only referred to Honko, for example, who considers it important to include the following points as fundamentals of the terminological analysis preceding the analytic formation of the generic concepts: 1 ) content; 2) form; 3) style (of performance); 4) structure (of the text); 5) function; 6) the frequency (of the appearance or the actualization); 7) distribution; 8) age; 9) origin. This is not presented here as an exclusive and final list of the features worth consideration, but as a useful illustration for purposes of orientation (Honko 1967, 22). Moreover, there are some elements (like the truth status), which should be included in those mentioned above, depending on the specific nature of the material. As far as the available empirical data allow, these points will be examined in this paper.

However, when the texts are created (and recreated) in the performance situation as a genre-specific verbal communication, the genre analysis also has to take into account the analysis of the performance situation and its social contexts, as has been increasingly done during recent decades. Thus, the subject of the genre analysis is no longer merely the documented text, but also the text as performance. When the analytical interest shifts from the analysis of the story to include the story-telling, also the genre analysis has richer potential. The story-telling can be analysed as verbal, social and symbolic situation of interaction, the nature of which is defined in the convergence the verbal text, the competence of the performer and the degree of the participation of the audience. This applies also to the genre analysis of the Nenets songs.

The paradigmatic shift of genre studies from the text or document oriented analysis to the analysis of the performance and context is not new as such. Abrahams (1981, 193), for example, presents such ideas about the social and interactive levels in genre analysis. According to him, the analysis has to be directed to the relationship between the performer and the audience, in clarifying the special strategies that the performer

\footnotetext{
${ }^{6}$ Bascom, William: The Forms of Folklore: Prose Narratives. Journal of American Folklore 78. Philadelphia 1965 (3-20).
} 
has to master while communicating in a given genre. This kind of performance analysis helps to provide a closer understanding of the emic genre terminology, otherwise left quite obscure.

Abrahams specifically refers to the role of the performer. While the oral tradition is realized particularly in performance, the performer has to be aware - in addition to the material performed - of the appropriate time and place for the performance of a given genre, the traditions of performance and, most of all, the art of the performing. (see Abrahams 1981, 195) This has been quit often the problem of the traditional genre analysis: the contextual structure of the performance and the analysis of the participants engaging in the interactive performance situation have been left out of consideration. The crucial point is that quite often the analysis of the performance and its textual and social elements leads to a better understanding of the generic distinctions. Thus the fundamental motive for genre analysis is not so much the segmentation and organization of the material corpus, as seeing it as the ethnography of communication. This way of thought leads naturally to the study of ethnic or emic systematisation of oral tradition.

Thus, I propose to base my study primarily upon the traditional view of genre in folklore studies, but to complement and supplement this with the notion of genre in terms of performance and interactive communication, where to do so will enable us to enlarge our perspective on the relationship between the Nenets song genres and the emic terminology. At the same time I wish to emphasise specifically musical analysis. As this is relatively under-represented in the study of folklore genres, this emphasis should thus add another level for the understanding not only to Nenets song genres, but to the discussion of genre more generally.

\subsection{The narrative songs}

The narrative songs are defined here as a genre which is based on narration and story-telling in sung form. The contents of the narrative songs are based on stories which are considered to originate from the, even undefined and legendary, past and to be true (cf. Tereshchenko 1990, 16). The stories themselves are typically long, both in terms of performance and story content: the performance may take several hours, even several evenings, and the events of the story may encompass years or decades.

The oldest narrative themes are filled with fantasy, and yet the overall scene tends to be highly realistic. The Nenets way of life is depicted in the songs in detail. The narrative songs thus serve as a kind of oral chronicle of the history of the people, their abilities, their relations to each other and to other ethnic groups, as also Khomich $(1976,60)$ points out.

As such, it is worth considering whether Nenets narrative songs can be defined as "epic", from the viewpoint of literary studies. If traditionally the "epic" is defined as a large cycle of stories concerning specifically identified archetypal heroes, Nenets narrative songs can not be held as epic, as the term would apply, for example to the Manas of the Kirghiz, Maadai-Kara of the Altaian Turks or Geser of the Buryat.

On the other hand, however, although specifically dealing with Finnish material, Kuusi defines epic as stories, "telling about events larger than life", and includes elements of hyperbole, enumeration and stock epithet (Kuusi et al 1977, 13). All of these all characteristics can be found to some extent in Nenets narratives also.

Discussing about the definition of the oral epic, Honko $(1995,117)$ refers to the characteristic compositional length of the epos, to its narratological characteristics and 
composition, and especially to its meaning as the reflection of the identity of its owners. This view incorporates the question of the meaning of the epos beyond the local social units: the archetypal hero of the epic is known also outside of the local community and particularly in this kind of case the epic also forms, and may be deliberately constructed as, a possible basis for the identity of an ethnic or national group of peoples larger than a local community.

Since the Nenets do not have precisely these kinds of archetypal heroes known by every community in their songs, should their narrative songs be excluded from this definition of epic? The difference can hardly be considered as categorical, but as a continuum: a single community of nomads, or the people of a given tundra region, form as such a large regional ethnic unit, although the population rates would be minimal and would represent only a small fraction of all the Nenets.

The narrative song terms discussed below are syudbabts, an ancient type of heroic song; yárabts, more recent heroic-biographical type and xinabts, an even more recent category of songs, that can also be of a narrative type. The laxanakos (fairy-tales) can also be sung, with a performance style similar to syudbabts and yárabts. Furthermore, the historical changes in the genre terminology have produced some transitional epic forms, like hinabts (discussed below). The syudbabts and yárabts have also later counterparts, labelled adjectivally as syudbabtsarka 'half-syudbabts', 'almost-syudbabts', or accordingly, yárabtsarka (Tereshchenko 1990, 26; 31).

\subsubsection{Syudbabts}

Syudbabts can be translated as a 'hero song' or 'giant song' (syúdbye, 'giant'; Lehtisalo 1956, 456), reflecting the fabulous giant theme, well established in several narrative traditions and mythologies around the world. Lehtisalo (ibid., 456) xints interestingly at the (etymological) connection between the word syudbye ('giant', 'giant goblin', 'forest spirit') and syud 'whistling', but offers no explanation for this. Although the two terms have musical connotations, the assumption by an outsider to the culture of a stronger semantic connection is problematic, especially in light of the major significance of vocal music and sung text in Nenets musical culture.

The giant theme is presented in some of the oldest documented texts of syudbabtses (cf. Castrén-Lehtisalo 1940). However, already Castrén's text collections made among the Nenets as early as the 1840's testify that the giant theme was already becoming secondary and rarer at that time. Although the contents changed, the syudbabts preserved its name, probably due to the earlier popularity of the giant theme. (Kupriyanova 1965,28 ) The giants are usually depicted as monstrous man-eaters, as embodiments of evil (see Tereshchenko 1990, 18), with which the hero is bound to confront in an unfair fight, but which he eventually wins by his bravery and wit.

Probably there has been a predominant "giant theme" in the oldest syudbabts, which has been replaced with the more general "hero theme" - as suggested by Kupriyanova and Tereshchenko. While the concept of a "giant" can also refer to the bravery of a (human) hero (syudbyadyo(s') 'to be self-reliant'; ibid. 18), it is plausible to suggest that the general hero theme has also been perennially central to the syudbabts.

There are similar narrative genres among the Eastern Samoyedic neighbours of the Nenets also. The Enets of the mouth of the river Yenisei have a corresponding genre called syudobichu (sudob'ichu 'Heldenlied'; Katzschmann-Pusztay 1978, 201). Unfortunately the Enets oral traditions are quite poorly documented and studied, so that there 
is only a mention of a kind of rough generic opposition among the Enets. The syudobichu, a "hero-song" has themes of wife-quest and tribal warfare, while dyurechu (dyorechu; 'messages') includes other types of tales, myths, historical beliefs, but also biographical themes. (cf. Dolgikh 1970, 136; Labanauskas 1992, 3) It is quite likely, however, that the organization of the song genres among the Enets is quite similar to that of the Nenets or the Taimyr Nganasan, who have also a similar narrative hero-genre called sitåbe (about the Nganasan songs and their genres, see Dobzhanskaya's (1995) recent study).

There are no definite distinctions between the Nenets various narrative song genres at the musical level. The generic differences are manifested mainly through the plot structure and the characteristics of story-telling. Thus, Nenets make more delicate distinctions within the prose narrative genres too (like wadako 'tale' or 'word utterance', laxanako 'fairy tale' or 'story') where the distinctive feature is usually the style of performance (Kupriyanova 1965, 20).

It is especially hard to reconstruct how the syudbabts sounded in the 19th century. Moreover, subsequently the epic subtypes have all somewhat merged with each other thematically and by their styles of performance. The clearest musical distinction, often mentioned (e.g. Lapsui 1993), is that syudbabts is sung throughout with one melody, whereas in the yárabts the melodies may change corresponding to the different actors in the song.

The narrative form in the syudbabts is closely related to fables. The actors in the story may have supernatural powers, they can transform themselves into animals, fly in clouds etc. The hero is referred to in the third person, which shifts the emphasis to the events of the story, and not to the individual as in yárabts. The scale of the events in the story is often drastically hyperbolized: the journey may last many years through several lands, the warriors may fight with each other ten years on the same battlefield, and so on.

One of the main characteristics in the storytelling - especially in syudbabts - the distinctive personified internal narrator, wada-syudbabts ('word-syudbabts') or minyeko ('undefinable character'; Laptander 1991; Puiko 1991; Tereshchenko 1990, 25; 117; 319 ), who defines the opening scene in the story through the mouth of the performer. Usually wada-syudbabts hovers freely over the tundra, and where something is going to happen, it zooms to the places of further action. (cf. Kupriyanova 1960, 130).

Discussing the characteristics of syudbabts with the Nenets, there was an occasion when a young reindeer herder in Polar Ural thought for a while and then responded: "Well, syudbabts... it is a mineko... While the xinabts and syo are sung and transferred among the name of the singers, the main acting entity in the performance of the syudbabts is the mineko." (Laptandyer 1991)

Also the Northern Komi, the so-called Izhma Komi, living adjacent to the Nenets and having been mixing with the Nenets ethnically, have a similarly functioning agent in their narrative songs. The Izhma Komi describe this agent either as a "proverb" (pöslevitsa; Russ. poslovitsa), as an "original singer” (körennei s'ilis'; Russ. korennoi 'original'), or as an "original teller" (körennei moidis'). The Komi singer may say, that "it is the körennei s'ilis', who is telling, not me». Also the Southern Khanty have narratives with similar internal narrators, called as "the person from the song or tale". (Mikushev 1987, 20)

The Nenets wada-syudbabts helps and guides the hero. When the story is over and the events completed, there is no further need for the wada-syudbabts, and the story can be properly concluded (Kupriyanova 1965, 38). Wada-syudbabts acts in some tales too. It is possible that this kind of personified entity may have played a more important 
role in the Nenets tradition in general (ibid., 39). It may even have had some kind of mythical meaning (ibid., 131).

The first example is the beginning of a syudbabts about the adventures of syudbya-father and his sons. The note transcriptions enclosed here are structural and paradigmatic. They are structural in the sense that the purpose here is only to show the main features of the melodic lines. The stylistic details (e.g., details in rhythm or pitch) are not shown here. It is paradigmatic in the sense that the bar lines correspond to the borders of the text lines, and the corresponding melodic lines (or motives) are placed vertically, so that the recurring melodic motives and lines corresponding each other can be seen more clearly. The different melodic lines are labelled with capital letters $(A, B, \ldots)$, and the order of the rest of the lines in the song is shown in the end of transcription. If there is a notable rising of the basic pitch, it is shown in the beginning of the transcription, where the pitch name in quotation marks refer to the pitch in the transcription, and after that is shown the original basic pitch (continuum). I have usually not included a time signature in these transcriptions. The musical metre is shown only in the paradigmatic layout of the transcription (about the metric analysis in closer detail, see: Niemi 1997b).

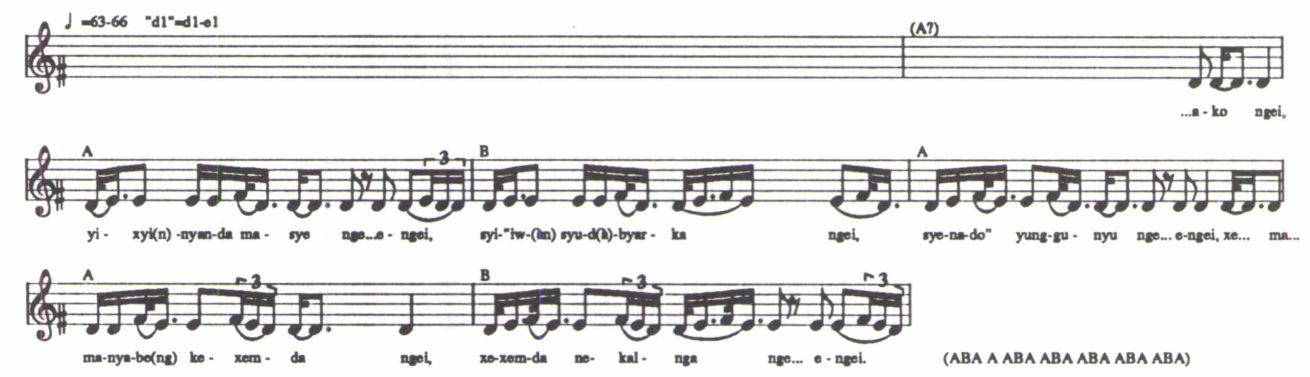

Example 1. Syudbabts (a fragment from the beginning). Performed by Maria Maksimovna Lapsui, in Nida, Ob Gulf, 1978. Recording, transcription of the text, its translation into Russian and commentary by Anastasia Timofeevna Lapsui. ${ }^{7}$ Further transcription, translation into English and transcription of the singing by J. Niemi.
[Syudàbya we $]^{8}$ sako ngei yixyinyanda masyi nge... ngei
— Syi"iw(àn) syudàbyarka ngei
syenado" yunggunyu nge...e-ngei.
(xe-e ma)
Manyabe(ng) kexemda ngei
xexemda nekalnga nge... e-ngei.

The old syudbya thinks to himself:

- My seven syudbya-sons, your footsteps are not heard (for a long time)?

His stone-idol, his idol he grabbed.

\footnotetext{
${ }^{7}$ There are not much Nenets songs recorded. The biggest collections are in personal archives of the individuals, the Nenets, local and foreign researchers and enthusiasts, but also the local radios (in Nar'yan-Mar, Salekhard and Dudinka) have interesting collections. There are also few published records including Nenets songs: Syoyotey Yamal (Melodiya S90 27639 003); Pod polyarnoy zvezdoy: traditsionnyi i sovremennyi nenetskii i pechorskii fol'klor (Melodiya M90 48949 008); Samodeyatel'noye iskusstvo narodnostey Severa (Melodiya S90 19759 007); Muzyka severnogo siyan'ya (Melodiya S90 30129 001).

${ }^{8}$ The first words were left out from the recording.
} 
The old syudbya asks his stone idol, the xexe, where are his seven sons. If his axe attaches to the idol, he can't get an answer. He asks, whether Ngesomutaki (an evil spirit, monster) killed his sons. The xexe is silent. No answer. He then tries asking, whether it was malevolent Siwanayaraxa. Again no answer. Then he asks, whether it was Ngewasyadeita. Now the idol jumps up into the air and hits the syudbya to his forehead so strong, that he falls to the ground. Now he got the answer, and the story continues from here...

\subsubsection{Yárabts}

Yárabts is the second subtype of narrative songs. The appellation is derived from the Nenets word yártsy 'to cry, to weep'. Thus literally, yárabts is translated as "crying songw. It is a song telling about the life and fate of an individual and it has sometimes an autobiographic nature. The "crying" comes from one of the most popular themes in yárabtses, namely the hardships and grief of the life of the hero in song (cf. Kupriyanova 1965, 40).

Although a "weeping song" yárabts must not be confused with, for example, the funeral laments of agricultural people, such as the Volga-Ugrian, Russian or Finno-Karelian. The Nenets have nothing like funeral laments at all (cf. Pushkarëva 1988).

Russian scholars maintain the yárabts to be of later origin than syudbabts, mainly by judging the thematic differences between the two song types.

The "classic" theme of yarabts is the hard life, suffering, fight and victory of the hero, presented in the first person (Kupriyanova 1965, 40-41).

While the theme types known in syudbabts - the bride-quest or the tribal warfare - appear mixed also in yárabts, it has two major themes prevailing. First, some of the yárabtses are heroic, and the narration concentrates on depicting the adventures of the hero and his relatives in a wife-quest or tribal feud. This type of theme is quite close to the themes in syudbabts. However, the way the events and adventures are presented is not so "heroic" as in syudbabts: there is more realism and humor in the yárabts. Lengthy passages in the narration concentrate on the life of the reindeer nomads: travelling with sledge caravans, preparations to such travels, catching reindeers etc. In the feud theme the narration concentrates more on the sufferings of the hero, than in the similar themes of syudbabts. Second, the group of other subjects of traditional life consists of various themes. The theme of intra- or intertribal warfare is present also here, but again, in more realistic way of telling. (ibid., 41-42) One of the most popular themes in this type of yárabtses, however, is the hardship endured by the hero. Usually the hero is a poor member, foster-child or a slave of a wealthy family. The family abandons the hero, and (s)he has to survive alone in the tundra, or on an icefloe on the sea. Finally the hero finds friendly people, and is able to return, in some stories for settling the relationships with his family (cf. ibid., 43)

Russian scholars often emphasize the change in the structure of the Nenets society as reflecting in the changing thematics of yárabts. Thus, quite often the hardships of the hero are due to his/her unequal and deprived position for example in the household of a wealthy reindeer-owner. Women characters are quite well represented in the yárabts, as well as the hero of the song or the performer.

The following text is as example of a yárabts with the classical tribal feud theme mixed with the hardship theme, with the central figures of a mistreated foster-boy and his female cousin, who turns to be the actual heroine of the story. 

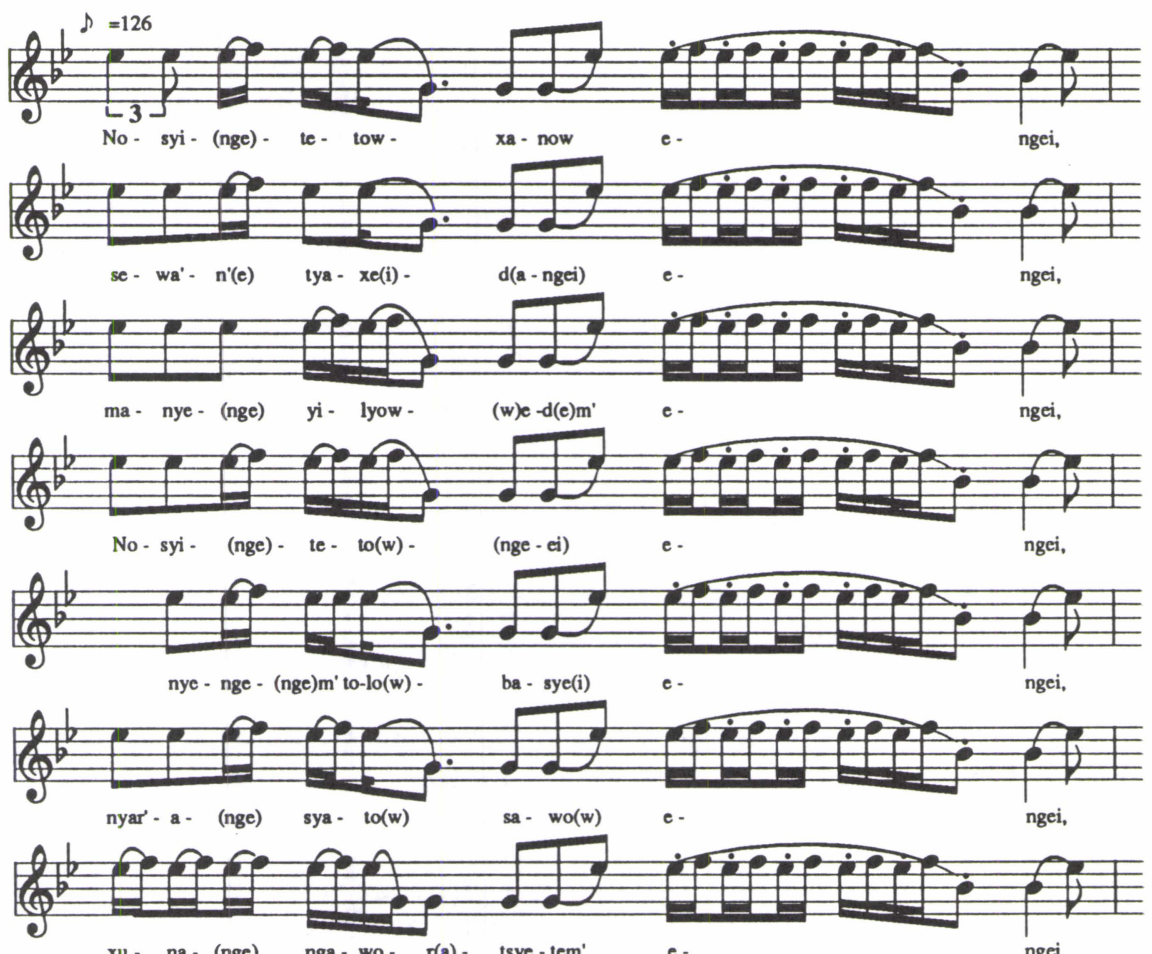

xu - na - (nge) nga - wo - r(a) - tsye-tem' e - ngei,

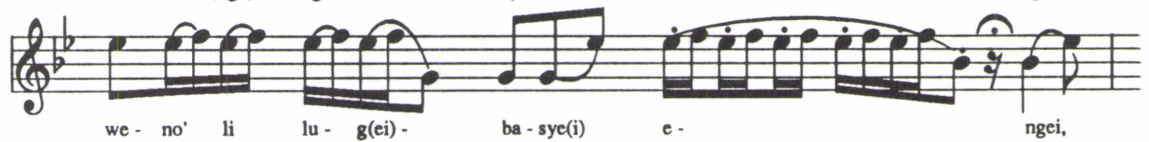

Example 2. Yárabts ("Atsyki»). Performed by Anastasia Egorovna Taleeva in Nel'min-Nos, Malaya Zemlya, 1959. Recorded and published by Z. N. Kupriyanova $(1965,544)$. Original transcription of the beginning of the song by B. M. Dobrovol'skii $(1965,766)$. Re-interpreted transcription by J. Niemi (in closer detail, see: Niemi 1997b).

Nosyi(nge)tetowxanow e-ngei sewan'(e) tyaxeid(a)(ngei) e-ngei manye(nge) yilyo(w)wed(e)m' e-ngei Nosyi(nge)tetow (ngei) e-ngei nyenge(nge)m' tolo(w)basye(i) e-ngei nyar(a)'(nge) syato(w) sawo(w) e-ngei xuna(nge) ngawor(a)tsyetem' e-ngei weno' li lug(ei)basye(i) e-ngei nyudya(nge) syato(w) sawo(w) e-ngei pida malye(i)syate(i) e-ngei xora(nge) yadow (nge)(ngei) e-ngei lexe'(nge) nyiwemnyo' ta'(ngei) e-ngei xarwa(nge-yei)nake(i) e-ngei le(nge)kom morye(i)syate(i) e-ngei luga(nge)basye(i)tin(ei) e-ngei tarye(nge)m' yilyowa'no(w) e-ngei
With Nosyiteta's, as long as I can remember, I am living.

The Nosyiteta have, if women are counted, three beauties.

Sometimes I eat

I gnaw bones

The younger of the beauties, she says:

— To my dog

I, seemingly, didn't give bones, she surely wants to eat.

She throws me bone, and I gnaw them.

This is how we live. 
ya(nge)bo' syid(ei)kat(ei) e-ngei ngob(e)'(nge) ngedo(w)lyodo(w) e-ngei tida(nge) malko(w)wu'mo(w)' e-ngei xoro'(nge) malko(w)wu'mo(w)' e-ngei to'mada myin(ei)xando(w) e-ngei Nosyi(nge)teto(wyiyei) e-ngei pida(nge) taryow' ma(ngei) e-ngei nye(nge)ko' pyiryo(w)(nga)do(w)' e-ngei yed(e)'(nge) pyiryo(w )(nga)do(w)' e-ngei myadoda to(ngow)nyo' (ngei) e-ngei myato(nge) tyulyo(w)(nga)do(w)' e-ngei yixi(nge)nyan(ei) mad(e)m' e-ngei

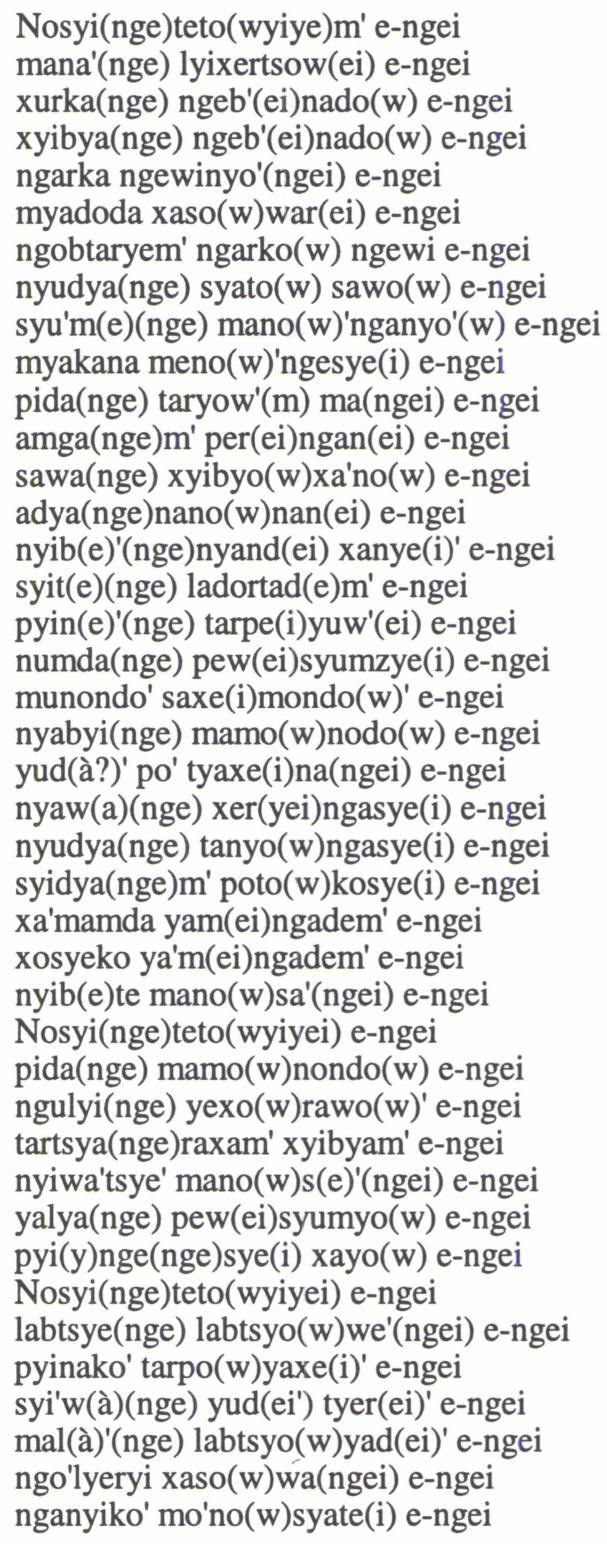

From somewhere

a traveller is approaching,

he has reindeers without antlers,

reindeer-bulls without antlers.

When he had arrived,

the Nosyiteta

said like this:

- Women, cook, cook some soup,

a guest has arrived!

They showed him the way to the hut.

I thought to myself:

\section{- At the Nosyiteta}

look:

what he looks like, what kind of man he is.

$\mathrm{He}$ is big,

but the guest

is also a big man.

The younger of the beauties

saw me,

and being in the hut,

she said like this:

— What are you doing (here)

amidst good people?

you can't be here,

if you don't go away,

I'll beat you.

I went outside.

When the evening came,

they talked all the time louder

one (of the guests) is talking (with a loud voice):

- Ten years ago

my brother left (for somewhere),

he had a son,

two years old (at that time).

His body I can't,

find, I can't find.

You haven't seen him?

Nosyiteta

he says (with a loud voice):

- We (really) don't know,

that kind of man

we haven't seen.

The day ended,

and the night came.

Nosyiteta (and the guest)

attacked each other,

they went outside.

The dwellers of (all the) seventy huts, they all attacked the guest.

This single man

falls down (all the time), 


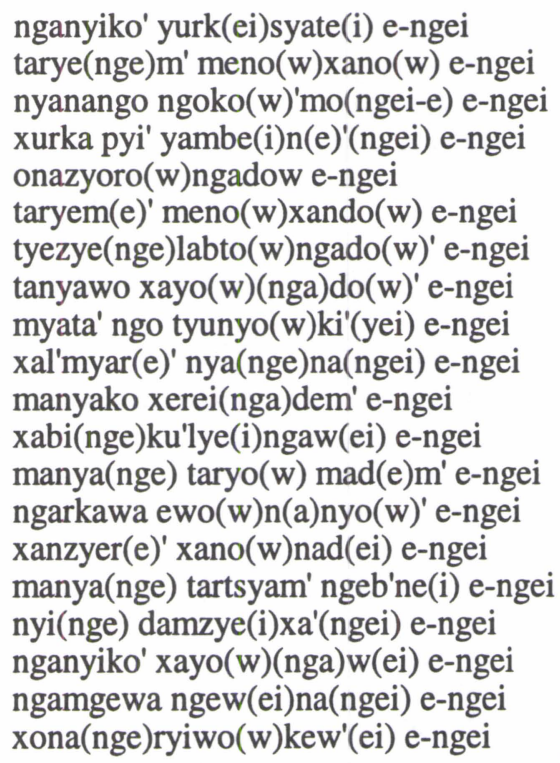

but rises up again.

They are fighting like this, there are so many (attackers),

The whole night

they beat him, and finally like this, they killed him.

They left him there, and everyone went back to their huts.

To the dead man,

I went.

I looked at him, and I said like this:

- You look like so big a man, how could you die?

If I had been like you,

I wouldn't have died.

I left him.

What else,

I (went back and) laid myself down to sleep.

This story continues with a chain of events:

The Nosyiteta-master goes off for a wife and returns. After a while the Nosyitetas decide to sacrifice the foster-boy to spirits. The new wife, however, helps the boy to escape. The boy escapes to the tundra. After a long time he finds the same woman again. The woman tells him that the man the Nosyitetas killed, was his father, Khorateta, who went looking for his brother (who had a baby boy). Eventually they find out, that they are cousins.

The Khorateta boy lives with his cousin for years, and when he is big enough, he goes to search the Nosyiteta-master and takes revenge by killing him. On his way back to her cousin, he meets the family of the Pakhasyedyiteta, whose son turned out to be about to marry the eldest daughter of the Nosyiteta. Leaving the hut of the Pakhasyedyiteta, their son cries now for revenge for the killed father-in-law and goes after the Khorateta. The Pakhasyedyiteta gets him and beats him almost to death. In the last moment his cousin finds him and cures his wounds.

After recovering, the Khorateta wants to go for Pakhasyedyiteta and beat him in turn. Pakhasyedyiteta is living with the Nosyiteta daughters, when Khorateta arrives. However, the Pakhasyedyiteta wants to settle their hostilities. He says that he didn't marry the eldest Nosyiteta after all. Now the positions have changed, and the Khorateta throws bones to the Nosyiteta daughters who live now with them as slave-like servants. The Nosyiteta offers his sister to Khorateta. They agree and have a wedding. Khorateta, in turn, promises his cousin to Pakhasyedyiteta. They return to Khorateta's camp and now the Pakhasyedyiteta and the Khorateta-cousin get married.

They are living together, the family and the reindeers of both Pakhasyedyiteta and Khorateta. After a while the Pakhasyedyiteta and Khorateta split their wealth and continue living separately. Khorateta's cousin Pakhasyedyiteta's wife, that is - advises eventually that Khorateta should take the youngest Nosyiteta and she takes the eldest Nosyiteta (for Pakhasyedyiteta) as second wives.

The final battle begins, when Pakhasyedyiteta hears that (the pro-Nosyiteta) 
enemy is gathering warriors to attack them, after having found the body of the Nosyiteta-master. The warriors come and they fight. Eventually only the youngest Yamal and the youngest Tungus ${ }^{9}$ of the enemies are left and they run away. Pakhasyedyiteta goes after the Tungus and Khorateta after Yamal. However, both the enemies are stronger than Pakhasyedyiteta and Khorateta. The Khoratetacousin arrives again in the last moment, to save both of them at a time. Returning, the Khorateta cousin sees that the warriors are after them again. She tells the Pakhasyedyiteta and Khorateta to go back and not worry about her. They go to their camp and continue living with their families, having already children running around. They wait for the Khorateta cousin, being sure that she has killed. After a long time the Khorateta-cousin arrives, alive. She claims finally the leadership of the families to herself and the Pakhasyedyiteta and Khorateta agree (Kupriyanova 1965, 544-565).

Unlike syudbabts, in this narration the primary interest concentrates on the actions of the hero and the narration is conducted by the hero. However, the hero is presented as merely an actor, and the inner thoughts and feelings are not much depicted (ibid., 53).

There seems to be slight regional variation in the generic concepts of the narrative song types. Mostly the syudbabts and yárabts are considered as narrative songs proper, but especially among the Eastern Nenets the xinabts (see below) can be of narrative character too.

\subsubsection{Themes in narrative songs}

Overall, and especially in the old narrative texts, there are some recurrent themes, such as a quest for a wife (from a faraway country), feud, battles between families or tribes and the giant theme among the most ancient themes.

Russian scholars maintain that the essential differences between the syudbabts and yárabts are more clearly seen when these types are'put into their historical contexts. According to this opinion, the most crucial ethnohistorical factor is the gradual shift from the clan-based community type to the family or neighbourhood type. The disintegration of the clan community is seen as a slow process lasting for centuries and being connected with the period of the more extensive Russian settlement of the Arctic North beginning in 17 th and 18th centuries. The system of internal solidarity changed gradually to a regional, neighbourhood-based community type. At the same time, the reindeer economy changed gradually from wild deer hunting to the reindeer-herding proper. This meant also concentration of the reindeer herds as units of wealth and it has been interpreted (most eagerly by Russian scholars in Soviet time) as the original phase of economic inequality among the people. (cf. Tereshchenko 1990, 11-12) The attitudes toward subsistence changed accordingly: the subsistence possibilities were defined according to the output of work power in a neighbourhood, not by its members' affiliation to a clan. The trade economy was introduced. (cf. Khomich 1966, 142)

The themes of warfare and wife-quest, as presented in syudbabts, along with the hyperbolization typical of archaic wondertales are seen in terms of characteristics of the patriarchal clan society. However, the variants of these themes in yárabts,

\footnotetext{
${ }^{9}$ These names refer to distant enemies: the other being a Nenets one from the Yamal and the other being an Evenki one, from yet more distant regions of the Central Siberia.
} 
emphasizing an individual and his/her sufferings are seen as appearing in the last phase of the historical disintegration of the clan society. In any case, the multitude of different theme and plot types of the yárabts can also be seen as indicative of its appearance later than syudbabts. (cf. Kupriyanova 1965, 55-56)

\subsubsection{Performance}

The performers of the narrative songs have to be specialized in their task, yet they are not professional in the sense that they would require a payment from a performance. They rank high in social status, if they are good. They have to be good in order to have public and to keep its interest in a story lasting for hours (even several nights) (cf. Barmich 1988). They have served a period of learning the practice as a novice, under the supervision of a senior performer.

As such, many of the epic texts tend to repeat the same thematic types of stories. Therefore it is up to the performer to rekindle the story and the audience. He/she has to be able to improvise details in stories. Usually a good performer has performed all his/her life (cf. Kupriyanova 1973, 173; Tereshchenko 1990, 17; Puiko 1991).

The story itself develops very slowly and with abundant repetition (Kupriyanova $1973,177)$. One of the main characteristics of the repetition structure and of the performace conventions of the epic songs in general is teltanggoda 'repetitor', an assistant to the perfomer. The teltanggoda repeats in condensed prosaic form the passages sung by the performer. The assistance of the teltanggoda is very important in the traditional performance situation, but if there is no such person available, the performer can act as a teltanggoda himself (Barmich 1988). Repetition is needed, because the performer may use archaic, obsolete expressions, or his sung words may be hard to catch. If the singer thinks, that the teltanggoda seems not to be able to do his/her job, the singer may tell him to stop and ask somebody else among the audience to continue as a teltanggoda (Tokholya 1991).

By its performance structure, the yárabts is closely related to the syudbabts, in particular in its repetitive character in narration and the need for a teltanggoda-assistant in performance. However, the character of the reality and the events in the song is not so heavily hyperbolized as in syudbabts.

Here is a fragment from the beginning of a yárabts performance with a teltanggoda repeating the singers words. 

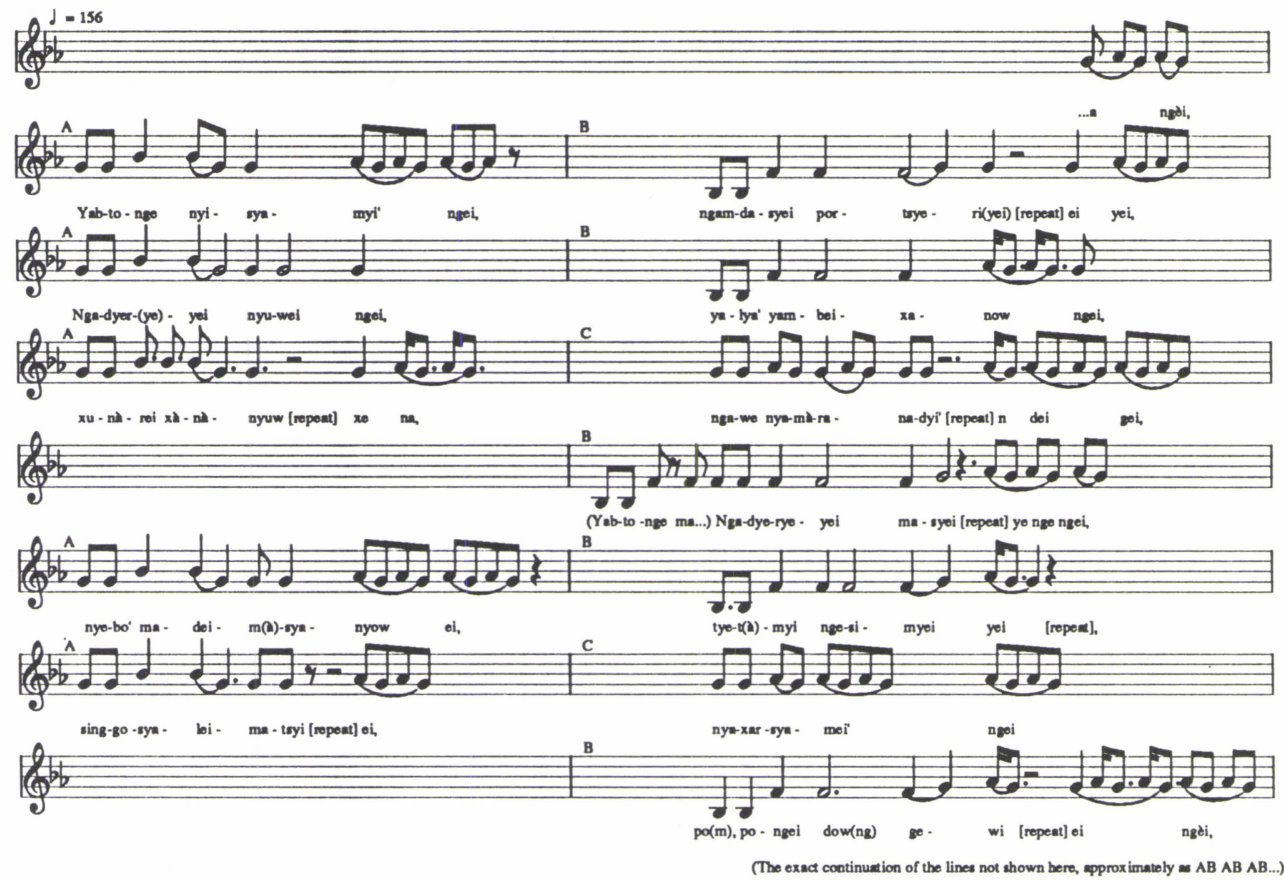

Example 3. Yárabts (with a tribal and a hero theme close to syudbabts; a fragment from the beginning). Performed by Laru Khoralya and an unknown teltanggoda, Southern Yamal in the 1980's. Recording by Vera Larovna Khorateta (née Khoralya). Transcription of the text, translation into Russian and commentary by A. T. Lapsui. Further transcription, translation into Englisf and transcription of the singing by J. Niemi.

...a ngei, Yabtonge nyisyamyi' ngei, ngamdasyei portsyery(yei) (...) eiyei, Ngadyerye(ye)i nyuwei ngei, yalya' yambeixanow ngei, xunàrei xànànyuw (...) xe na, ngawe nyamàranadyi' (...) $\mathrm{n}$ dei gei, (Yabtonge ma...)

Ngadyeryeyei masyei (ye) (...) nge ngei: nyebo' madeimsyanyow ei, tet(à)myi ngesimyei (...) yei, singgosyaleimatsyi (...) ei, nyaxarsyamei' ngei po(m) pongei dow(ng) gàyà (...) ei ngei, ngesimyi' pyunggudei (...) ei(yà) ngei,

\author{
My father Yabtonge \\ abruptly raised sitting (having been lying down). \\ Son of the Ngadyer \\ for days \\ has been driving somewhere, \\ catching (or hunting) something? \\ (Yabtonge say...) (= mistake of performer) \\ Ngadyer' says: \\ - Last year I said to you, \\ from our four herds (=reindeers and herders) \\ there is no messages \\ for about three years. \\ (Three) years has passed. \\ I want to search for these herds.
}

Interestingly, this role is related to that of the assistant (also called teltanggoda) of a shaman too, but there this kind of mediator is needed, because the words of the spirits are considered dangerous to human ears and so it requires a mediator, a repetitor (who was also devoted to shamanistic action as an assistant and a novice), as suggested by Pushkarëva (1992). 
Gennadii Puiko (1991) has an interesting notion about the sacral nature of the syudbabts. He considers that syudbabts is a sacred "heavenly song", whereas the yárabts and xinabts are not. As evidence he refers interestingly to the close connection between syudbabts and the shamanistic worldview. "Syudbabts is the kind of thing, when there is transformation (i.e., in which the hero of the story transforms himself) into something else, to a beast or a bird. And the enemies can transform as well. If the pursued transforms to a fish, then the pursuer transforms to a pike. All as in nature. If the pursued transforms to an iron reindeer, then the pursuer transforms to an iron wolf. It is all as in nature."

The sacredness is thus primarily connected to the role of the performer. Puiko continues by saying, that "as I have been noticing in my life, these performers of syudbabts are mostly the kind of persons, who master some kind of supernatural powers. They know the seven spheres (of the Nenets mythical world view) well... There are some people (i.e., performers) so familiar with that, that I can't imagine, how much room there is in a man's head! These kind of people may perform, say, three days, perhaps a whole week. It is usually considered, that there isn't room for all of that in the head of a normal man."

Puiko sees the sacral side of the performance structure in the following terms: "...And you must not interrupt these heavenly, sacred songs. Why? There was an incident (in the song), that two caravans of reindeer sledges met each other. They stopped on a big hill-top. The word-syudbabts minyeko noticed, that they stopped. Then the performer says: "Listen buddies, I'll have a break, let them (i.e., the crew of the two caravans in the song) talk meanwhile. (And the performer had either a long break or didn't continue the song at all anymore.) And suddenly, at night, a person came down from the hill-top to the performer. (He said:) "Oh, how we already have talked for ten years, all the words we have already spoken. We are tired, reindeers have nothing to eat anymore, we just stand here. After all this time, you would also hate this place?" When the morning came, the performer died, after having told this dream of his. He made sin, he left people and reindeers on the road. You must not interrupt the song." (Puiko 1991)

This kind of attitude towards the storytelling can be seen as a reflection of the Nenets animistic worldview. Performers can and they must have breaks in a song lasting for days (or nights), but it is considered safe to time the moment of interruption to a quiet, serene or transitory passage in the story, so that they would not leave the actors of the story to stand in one place for years, the reindeers dying for hunger or tribes fighting the same fight for years. Thus the figures in the song are considered as entities, that must be taken care of, even outside the performance. In this sense the wada-syudbabts can be interpreted not only as a means of moving the story forward, but also as a transitory passage in a song, through which possible performance interruptions are possible. The song can be safely concluded, when the wada-syudbabts/minyeko, an undefinable character, is again left hovering in the wind.

In this respect, also Grachëva presents a notion about the hypostatic conceptualisation of the Northern peoples: in the Nganasan worldview an individual first has a connection with the environment and its powers (actual or believed). Second, (s)he conceptualizes these forces specifically as hypostatic, as embodied in the concrete phenomena in the environment, like the wind or animals. And it is the speciality of the shaman to deal with these personified forces, with the ability to transform himself into such a force. (Grachëva 1983, 129-130) This kind of transformation thinking is quite typical of the oldest narrative songs. 


\subsection{The owned (lyric) songs}

Lyric songs, of which the majority are songs specifically owned by an individual, are in general conceptually the most accessible category among all the Nenets songs. However, they are far from unproblematic, because they include a concept of personal, intimate, even a secret song of everyone's own.

Pushkarëva $(1990,81)$ notes, that these personal song-improvisations are also characterized by their non-traditional nature in terms of the creation of the song (performance). Interestingly, Pushkarëva's attitude is connected to the interpretation of the concept of folklore as anonymous, shared tradition. In this sense, she sees the personal song as an idiosyncratic, individual creation, which should be paralleled in a way with the individual composition and textual traditions of a high culture. While this can be thought of as a logical parallel, it is still, in my opinion, most suitable to regard personal songs as an institution in the context of a traditional culture, although the songs are based on individual and idiosyncratic creation.

The vast majority of the songs of this type - especially the personal songs - are songs that people make for themselves. The singer-performer is not necessarily an expert like the singer of a narrative song. If the song is an individual song, it is not necessarily meant to be performed in the public, except among the closest relatives and in certain situations (see below: the yábye syo).

Is it possible to define the differences between the structures of epic and lyric narration? It is not sufficiently recognised that, while a lyric song (text) can be seen as a form of narrative language, which is used as a means of communication when trying to visualize an event or experience, at the same time it can be central in other forms of narration and storytelling too. The differences between the types of narration can be approached in terms of how to organise the flux of events in time and space. While the epic narration usually tends to give a logical, linear account of what is happening (where and in which order, in relation to the preceding or following events), the lyric narration tends to concentrate on expressing a more limited account of events in terms of time, space and logic of the events. However, the form of lyric narration can be much more diverse in mixing and blurring this time-space-order-continuum with the complex inner logic of emotions of an individual. Thus the narrative logic of the epic can be more easily understood than the logic of the lyric narration.

Simoncsics's notion about the semantic isomorphia in a lyric song text is, in my opinion, fruitful, if the conceptual or generic identity of the "lyric song" is pursued. According to him, this semantic isomorphia should appear as a kind of relational semantic autonomy of a text line, or a pair of text lines (cf. Simoncsics 1978, 401-402).

Thus, whereas an epic narration can be seen as linear, conforming to the expectations of the logic of text narration, a lyric text may not give such a strong impression of a continuum of meaningful pieces of information, but rather an expressive whole, where the function and meaning of single lines or line pairs can be understood only in terms of themselves or in relation to the whole. A lyric text does not explain things in the way an epic narration does. It leaves many text lines hanging, adding only a good poetical "sound" to the composition. In the case of the Nenets personal songs (see below) this is particularly clear. The song text functions as a kind of veil or filter, through which the outsiders can understand only the surface meaning and the insiders can guess (if they don't know already) the real meaning behind the words and expressions sung.

Thus, these owned or lyric songs can be distinguished from the narrative songs by their contexts of performance and creation, by their (textual) structure and by their age 
(cf. Kupriyanova 1960, 240).

The role and essence of improvisation is also worth consideration. The "lyric" songs are often defined as "song-improvisations". However, the Nenets owned songs are not randomly improvised as such. The song text - if it is meant to be a sung equivalent of a person as in personal songs - has its firm structural fundamentals both at the level of text and melody. It depends only from the singer's and situation's mood, what fraction or perspective (s)he chooses for the moment. Besides, if the song has an autobiographical content, the logic of the textual composition corresponds to the logic of the biography of an individual. And as to the melody, the singer usually tends to rely on the basic personal melody types (s)he has created from the background of his/her social environment (cf. also Gomon 1980, 206). Seen as a whole, however, it can be argued, that the isomorphic text and melody structure in Nenets songs in general contains improvisation and variation only at the micro level, i.e. in the details of interpretation and intonation.

\subsubsection{Xinabts}

Xinabts is one general category of distinctive Nenets song, a kind of fundamental for classification of the song types, as proposed by Kupriyanova $(1965,21)$. Lehtisalo's explanation for the word is simply that of a song type derived from the verb xinóts 'to sing (a Nenets song)' $(1956,187)$.

By xinabts is sometimes referred to a short song-improvisation (of a personal character), sometimes as a longer narrative song (of autobiographical, personal or other, non-authored epic type). Part of the conceptual confusion may be explained through regional differences in the use of the word. The Western Nenets use a dialectal form "xints" or "xinàts" to denote a short improvisatory song comparable to the syo song type (cf. Pushkarëva 1988) and the Eastern to a long narrative, reminiscent of yárabts (cf. Lehtisalo's (1947) text transcriptions of xinabtses).

However, there are also longer and more narrative xints among the Western Nenets too. Thus, the main conceptual difference is, that in the West the xints means either a personal song or narrative song (which may also be of personal and autobiographical nature), in the East (from the tundra of Bol'shaya Zemlya) the xinabts means mainly a longer narrative song, reminiscent of yárabts.

An example of a narrative xinabts (xinàts) of the Western Nenets is a story of a boy, an elder brother, who was reluctant to have the wife that his father was about to get him, but after all wanted to have the wives his father arranged for his younger brother. 


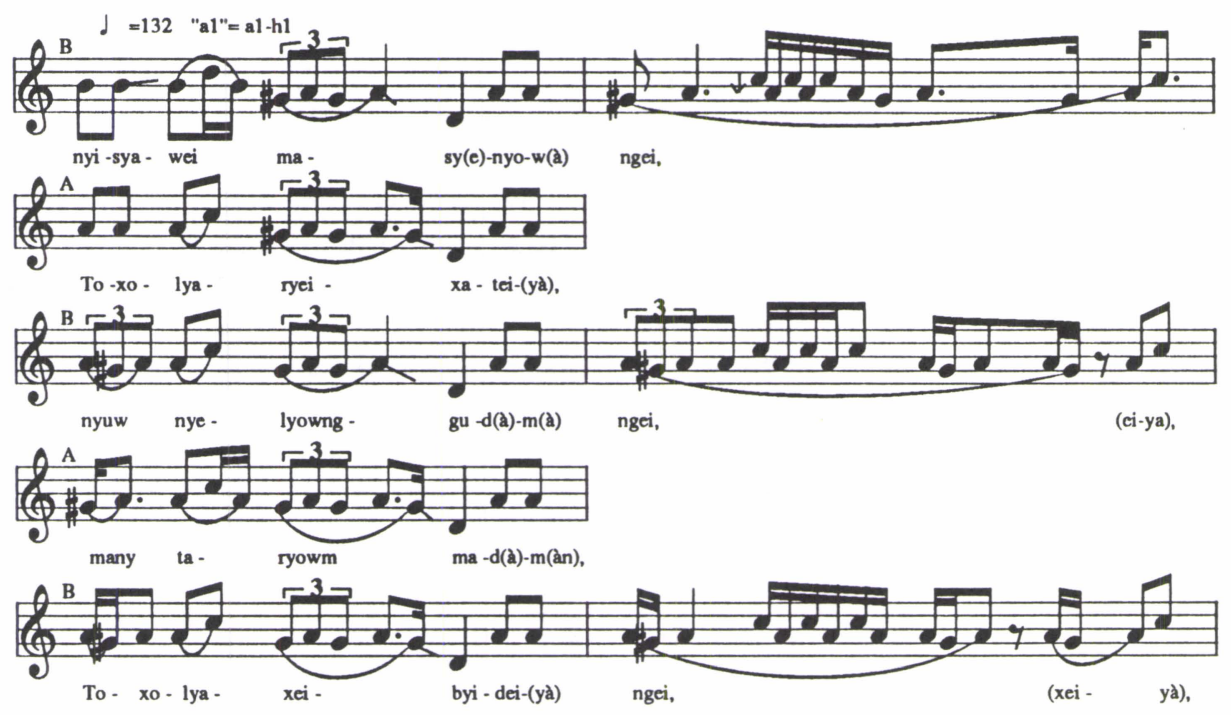

(AB AB AAB AAB AB AB AB AB AAB AB AB AAAB AAB AAB AB AAB AAB AAB AAB AB AB

AAB AAAB AAB AB AAB AAB AB AAAB AAB AAB

$\mathrm{AB} A \mathrm{ABB} A \mathrm{AB} A \mathrm{AB}$ A (A...) AB AB AB B AB)

Example 4. Xinabts. Performed by Paraskov'ya Nikolaevna Maryueva (née Taibarei) in Nel'min-Nos, Malaya Zemlya, 1994. Recording by J. Niemi. Transcription of the text and translation into Russian by A. T. Lapsui. Further transcription, translation into English and transcription of the singing by J.Niemi.

nyisyawei masy(e)nyow(à) ngei,

Toxolyaryeixatei(yà), nyuw nyelyownggudam(à) ngei, (ei-ya), many taryowm madàm(àn),

Toxolyaxeibyidei(yà) ngei, (xei-ya), tangotow(àn) siretow(àng),

kalyaryim(àm) ber(e)tyow(à) ngei (ng, ei-yà),

yenzy(à)ryinowkiyei(yà), tenz(à)yadowkiyei(ya) ngei ng (I), nyisyawei(yà) masy(e)nyow(à), pi(dà)r(à) nyàbatei xar(à)wow(à), nyuw nyudyow nyuwei(yà) ngei (ei-yà), nyu nyelyownggud(à)m(à), nyisyawei(yà) xayanyow(à), pido nyaxar(à)ngesyei(yà) ngei ng (xei-yà),

nyaxarkawow yalyow(àn), singgaryodow" yanggow ngei (ei-yà), nyaxar(à)" ngesowngganow(à), syenzy(à) yaly(à)nyow dongow(à) ngei (ei-yà),

Toxolyitei papow(à), nye xam(àn) taryeiwiyei(ye) ngei (ei-ya), nye syadowmiyei(yà),
My father says:

- From the family of the Tokholya

I want to take a wife for my son.

I replied him like this:

- Your precious Tokholyas

all the summer, all the winter

eat the same single fish (= they are not wealthy)

And she may be a red-face, or a pale-face? (= not very pretty)

My father says:

If you don't want to (have this wife),

my younger son

my son I'll have married.

My father went off,

The three of them (went off) (= father, mother, younger brother)

For the whole three days there was nothing heard of them. At the end of the third day the sound of jingles was heard (= the bells in a sledge)

The sister of the Tokholya-brothers, this girl they brought (with them).

A pretty-faced woman, 
nye myiryeimiyei(yà) ngei (ei-yà),

nyisyawei masy(e)nyow(à),

yewànzadowkowei(yà),

myud(à)rei(yà) ngedasyei(yà) ngei ng (ei-yà),

nyaw papowkowei(yà),

myud(à) ngedeinganyow(à) ngei, (ei-yà),

ngob yaxandyow yasei(yà),

yan nyi xaw(à)row(à) ngei, (e),

myat(àn) tyuwowkiyei(yà),

manya" ngam(àn)deiyowei(yà),

syidya sawow nyandei(yà),

pond(à) ngam(àn)deiyowei(yà) ngei, (ei-yà),

many daryowm madàm,

pydar(à) meb(à)tsowkenei(yà),

nganyim(à) meb(à)tsowkenei(yà) ngei, (ei-yà), nyisyawei(yà) masy(e)nyow(à),

kurkarei mengam(àn)dow(à),

yewànzadowkowei(yà) ngei (ei-yà),

pydar(à) ye"emeinyandei(yà),

nganyim(àng)' goteingawow(à) ngei (ei-yà),

nyan(à) nyengeim memei(mà),

nyisyawei xayanyow(à),

anyi ngodei ka(i)yow(à) ngei (ei-yà),

nyisyawei(yà) masy(e)nyow(à),

Tusy(i)dareixatei(yà)",

nyem(àn) tàteingawow(à)" ngei (ei-yà),

anyi" ngodei(yà) ka(i)yow(à),

nyaxarkawow yalyow(à),

singgaryodow yanggow(à) ngei (ei-yà),

nyaxar(à)" ngesowngganow(à),

yalya ngesowngganow(à),

syenzyi yaly(à)nyow dongow(à) ngei (ei-yà),

nganyi(n)' daryeiwiyei(yà),

nyi(ng)' gaman daryeiwiyei(yà) ngei (ei-yà),

Tusy(à)dyite(i) pa... pow(à),

nye syadowmiyei(yà) ngei (ei-yà),

nye myireimeyei(yà),

nyaw papowkowei(yà),

myud(à)m ngedeianyow(à) ngei (ei-yà),

myat(àn)' tyuwowkiyei(yà),

nganyi' ngam(àn)deiyowei(ya),

syidya sawow nyanei(yà),

pond(à) ngamdeiyowei(yà) ngei (ei-yà),

many daryowm madàm,

pidar(à) meb(à)tsyowkenei(yà),

nganyim(à)' meb(à)tsyowkenei(yà) ngei (ei-yà),

many(à) meryeingguwei(yà),

Dusy(i)dyitei papow(à) ngei (ei-yà),

nyisyawei masy(e)nyow(à),

yewànzadowkowei(yà),

xurkarei mengam(àn)dow(à) ngei (ei-yà), a pretty-figured woman.

Our father says:

- My youngest son

took off the harnesses from the reindeers of the sledges of the wife.

My youngest brother

gathered all the sledges.

And not a single harness-decoration

did he drop to the ground (= a good sign for the couple)

The newly married were taken to the hut.

I, pushing them aside,

sat between them.

Sat with force.

I said like this (to my younger brother):

- You have still time,

marry next time.

Our father says:

- Don't worry,

my youngest son,

for you

we set off once again.

And I took my brother's wife.

Our father prepared again

to the bridal journey.

Our father says:

- From the family of the Tusyda

we bring a daughter-in-law.

They set off again.

For the whole three days

there was nothing heard of them.

At the end of the third day,

towards the evening

the sound of jingles was heard,

the wedding sledges are approaching.

They brought a bride.

The sister of the Tusyda-brothers

a pretty-faced woman,

a pretty-figured woman.

My youngest brother

took off the harnesses from the reindeers of the sledges of the wife.

The newly married were taken to the hut.

Again, pushing them aside,

between them

I sat.

I said (to my younger brother):

- You have time all right,

marry next time.

I'll take her,

the sister of the Tusyda-brothers.

Our father says:

- My youngest son,

don't worry. 
nganyim(àn)' gob(à)tsowkewow(à)... ng kewow(a) nganyi(n)' ganyeinyimei(yà) ngei (ei-yà), wàr(à)" lyam(àn)sowryeyei(yà), nye(ng)' gam(àn) meb(à)tsowkewow(à) ngei (ei-yà), xeb(à)nyandowngodei(yà), nyisyawei donganyow(àng), kartyi(n) syidyowryisyei(yà), nyebyawei nyisyawei(yà) ngei (ei-yà), tob(à)nandowngodei(yà), nyaw papowkowei(yà), nyaw(à) xayowiyei(yà) ngei (ei-yà), tas(à)xawow pongei(yàn), singgaryodow yanggow(à), nyan(à) papowkonei(yà) ngei (ei-yà), tas(à) po(n) tewasyei(yà), syenz(i)" yaly(à)nyow songow(à)" ngei (ei-yà), nyaw papowkowei(yà), Yabtongetow papowm(à), nye(ng)' gam daryeiwiyei(yà) ngei (ei-yà), nye syadowmiyei(yà), nye myiryeimiyei(yà) ngei (ei-yà), maly(à) nyusoweyei(yà), yebts(à) xàreiyangow(à) ngei (ei-yà), nye xameinyiwei(yà), syidya lem(àn)sowredow(à), syidya sawow ngedow(à) ngei (ei-yà), tyusy(à)xateiraxow(à), many(à) daryow madàm(à) ngei (ei-yà), nyaw papowkowei(yà), menggudanowkerei(yà) ngei (ei-yà), tarsyi nyutei nyebyow(à) ngei (ei-yà), nyaw papowkowei(yà), xu nyidyow wetow(à) ngei.
We take off to search once again.

They set off once again.

This time they headed to

a woman dressed in rugs.

They went.

Father returned.

The both of them returned, mother with father.

Only they returned.

My youngest brother, brother stayed.

For the whole year there was nothing heard of him, from the brother.

After a year

the sound of jingles was heard,

My youngest brother

along with Yabtonge-brothers'

sister, returned.

A pretty-faced woman,

a pretty-figured woman.

They came with a baby, the baby's cradle in the front. (= to be surely seen) The brother's wife had arrived.

With worn-torn boots

in two pretty feet, pretty like polished.

I said like this:

- My youngest brother,

I have to give up, she is the mother of your child.

My youngest brother didn't much reply to these words.

Gomon has a theory about the conceptual content of the word xinabts. She maintains, that xinabts refers to a lyric song having, however, a larger meaning at the same time. According to her, the lyric xinabts is a modern, transitional song type, that preserves some stylistic devices of more traditional epic songs. Consequently, she thinks that the epic songs have (or rather: have had) a dominating position in the functional whole of the Nenets traditional song system. (cf. Gomon 1980, 206) Therefore xinabts sometimes represent a kind of "modern epic", with new themes and mixed performance practices. This is reflected in the need of a teltanggoda, who is sometimes desired, sometimes not. Pushkarëva, for example, reports of xinabtses of the Eastern Nenets performed with a teltanggoda (Pushkarëva 1992).

The word xinabts functions also as a component in compound concepts, through which the type of xinabts can be described more specifically. Thus, there may be ngedalyo"ma xinabts 'song of the (hunting) travel'; tyunya xinabts 'wedding song' or man yile'man xinabts 'song about my life' (cf. Bogdanov 1988) 
Syo is the second general concept of a song and singing and it also refers to a Nenets song in general. The most important songs labelled as "syo" are the personal, owned songs of a person. Etymologically it can be traced to a Uralic word root *sóye- ${ }^{10}$ 'throat', 'voice'.

It is worth noting that opposed to the concepts of xinabts and syo there is a special term for a song other than Nenets (e.g. a Russian song), yánggebts. The word is derived from a verb yánggerts 'to sing'. The word is interesting in the sense that it is a loan from Khanty (ianggem 'to play (games)'). Pushkarëva (1988) reminds, that yánggebts is not used much by the Eastern Nenets, and it can be assumed that among the Nenets the usage of this word originates from the lower Ob regions, where the Nenets and Khanty live mixed with each other. As a foreign song in general, the yánggebts has no specific individual character.

Some of the Nenets define the syo as "a short lyric song" and as "one of the categories of Nenets songs". They considered it different to the xinabts (cf. Pushkarëva 1988; Barmich 1988). According to Barmich, the xinabts (xints) among the Western Nenets (which she represents) corresponds the syo genre (Barmich 1988).

One of the main characteristics attached to the songs of the syo type has to do, however, with the ownership of the song. Thus, the word syo refers to a song owned by someone. Either it is a personal song or a drinking song.

Also the songs that are sung in the name of animals or natural phenomena (or supernatural entities as in shamanistic songs) are often referred to as a syo.

In the modern (sedentary) Nenets society, which is facing fundamental cultural change from the impact of the ex-Soviet and Russian urban and village culture, the concept of syo serves as a general term for "song", e.g. compositions of the Nenets composer of popular songs, Semën Nyarui (see below).

In the Soviet time there emerged a new tradition to include a concept of "Soviet songs" in classifications of the folklore of the indigenous Siberian people. Thus, the Nenets have "yedei syo" 'new songs', that were often filled with Soviet patriotism and "all-Siberian" pentatonic musical clichés.

\subsubsection{The individual song}

One of the varieties of the syo is the individual or personal song, denoted by with the name of its owner, like "Salyei' syo", 'the song of a Salyander (a Nenets surname) woman'.

There are strict rules for the performance of one's personal song. The composer of an individual song tends to sing it in solitude and maybe in the presence of the closest relatives, but not willingly to other people, especially to non-relatives. On the other hand, it is considered insulting to sing, or to reveal songs of one's close relatives, to strangers. These rules can be evaded, if the performer can be sure that the owner of the song doesn't hear her/his song performed by somebody else. In singing somebody else's song, the name of the author of the song has to be announced, although usually it occurs in the song text anyway. Owing to the personal nature of the song, another performer creates in fact another song, the interpreted, variant song, like imitating an

${ }^{10} \mathrm{Cf}$. Finnish soida 'to ring', to sound (music); soitin 'musical instrument'; suu 'mouth'. 
written autograph. In any case, with the author's name being incorporated every time the song is performed, it can survive long after its author has gone.

Although it is said that an owned personal song is something that is to be carried for the whole lifetime, the author, however, renews the song during his/her life. Thus the song matures along with its author.

The personal song functions also as a medium to describe and contemplate one's personal experiences, it can serve as a soother in long, solitary journeys in hard weather. On the other hand, the singing of someone else's song (in public) is a kind of social statement, an interpretation, through which the singer describes the owner of the song. Thus, in a way, personal songs function as an archive of human relations.

Pushkarëva has a folkloristic insight into the nature of ownership as a generic feature of the personal song. She maintains that these songs (i.e., song texts) have to be considered as an equivalent to the authored products of textual cultures, and not merely as a part of the (anonymous) folklore tradition. (Pushkarëva 1990, 81-82; 85)

As mentioned earlier, the real meanings of the texts in the personal songs are not necessarily meant to be understood by outsiders. The overt impression can be very sketchy and laconic, but those who know the singer and the song, can relate the text to its real meaning. The following is the opening passage of a personal song of a woman from Southern Yamal:
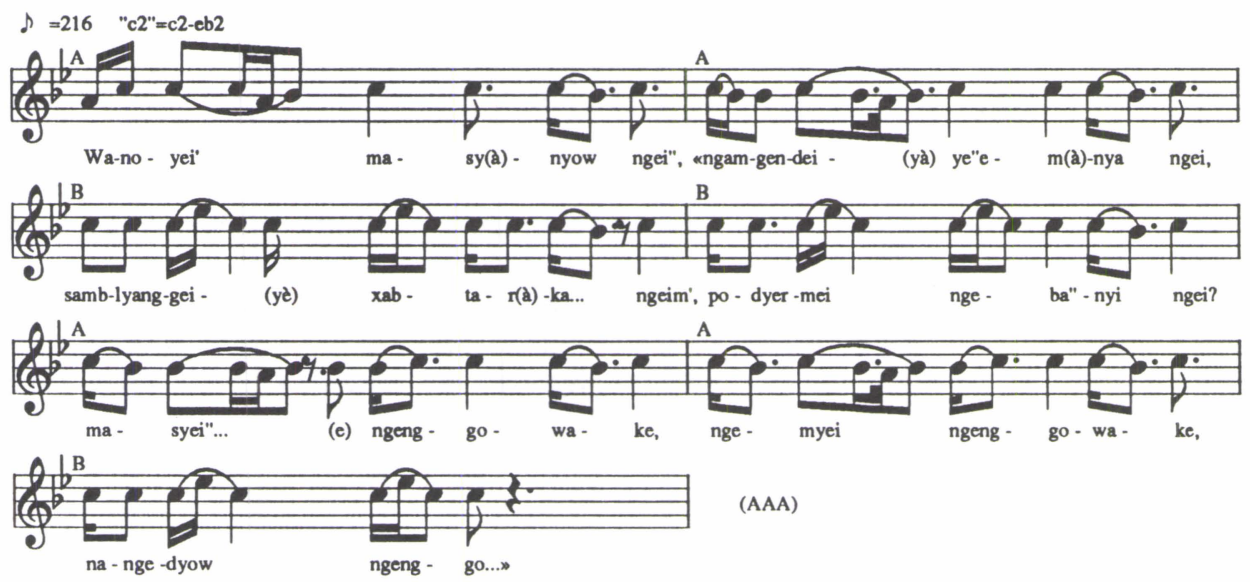

(AAA)

Example 5. Wanoi' syo. Performed by Angelina Vasil'evna Seroteta, Yar-Sale, 1991. Recording by J. Niemi. Transcription of the text, translation into Russian and commentary by Elena Grigor'evna Susoi. Further transcription, translation into English and transcription of the singing by J. Niemi.

Wanoyei' masy(à)nyow ngei", ngamgendei(yà) ye"em(à)nya ngei, samblyangg(ei-ye) xabtar(à)ka ngeim', podyermei ngeba"nyi ngei?

masyei" ngenggowake, ngemyei ngenggowake, nangedyow ngenggo(wake?), many(yei) taryem' madeim', masyi" ngedokiyei, ngemyi malyeiwamyi(m?)
It is Wanoi' herself talking (asking herself): «Why did (I)

five reindeer-bulls

harness?

Perhaps

My leg

would be unhurt?"

I say like this:

«Perhaps this,

that I broke my leg, is a sin?» 
The singer recounts, that she has harnessed five reindeers to her sledge, in order to drive somewhere. However, she complains that her leg is broken. Her leg seems to have been broken in a slight accident with the reindeer sledge during the drive. But this is not necessarily true, and not the whole story. In fact she is complaining that if she had not gone for drive, her leg and maybe the sledge would not have been broken. Why did she go in the first place, then? It seems, that she had some intimate affairs with someone in the tundra... And maybe she was married already...

\subsubsection{Yábye syo}

The personal songs are related functionally to another concept in the song system, namely yábye syo, the drinking song. The word derives from the verb yábyesy 'to get drunk'. I have chosen to use a specific entry for these songs, because it is a special concept for songs which are sung when the singer (and the audience) is drunk. Thus, it is more likely to hear someone's personal songs on occasions where alcohol is drunk, and people are less inhibited (cf. Pushkarëva 1988).

These songs are perfomed only when drunk. A yábye syo may be close to one's personal song, but it can be a different song, although an owned song too, depicting a drunk person. A person can boast extravagantly in a drinking song, he/she can pity his/her fate or express erotic feelings (cf. Kupriyanova 1965, 21; Lehtisalo 1947, 584).

Lehtisalo mentions the drinking songs as a variety of fate songs, in which a person describes him-/herself and his/her peculiarities. After having sung it (in a drunken state) and when someone else has heard the song, the song is reborn when someone else sings an interpretation of the song of the previous singer. (cf. Lehtisalo 1936-37, 34)

The external difference between a personal song and a drinking song is not necessarily very great; mostly their difference can be seen most clearly in the contexts of composition and performance of the songs. Lehtisalo $(1922,84)$ defines the drinking song thus: "Every individual has a song of her/his own, where (s)he sort of displays her/himself and her/his special personal features. These songs are often quite short, but they may be long as well, if a Samoyed is portraying some special event in her/his life; an adventurous seal hunt on an drifting ice-floe, etc."

The next song is a personal song with a performance feeling of a yábye syo: the expressive melody line and a slightly boastful text. At the same time, this song is an example of the singing style of the Forest Nenets, although it must be said, that here also, the question of the style itself is more easily explained on the individual than regional level. 
d. $=72 \quad " \mathrm{~d} 1 "=\mathrm{d} 1-\mathrm{fl}$
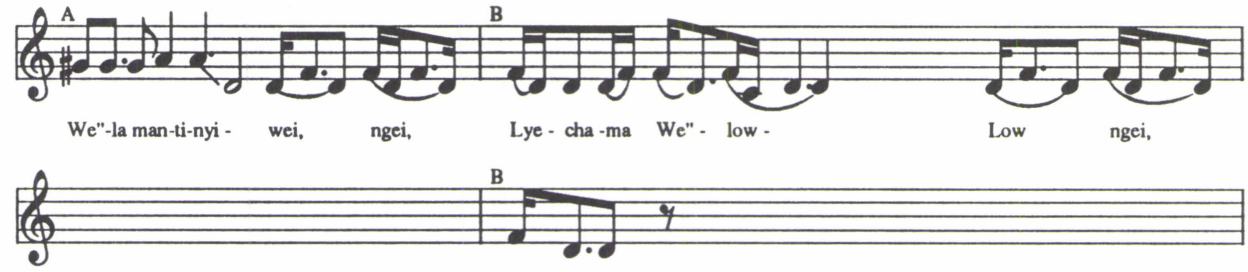

nyi - myi ka...
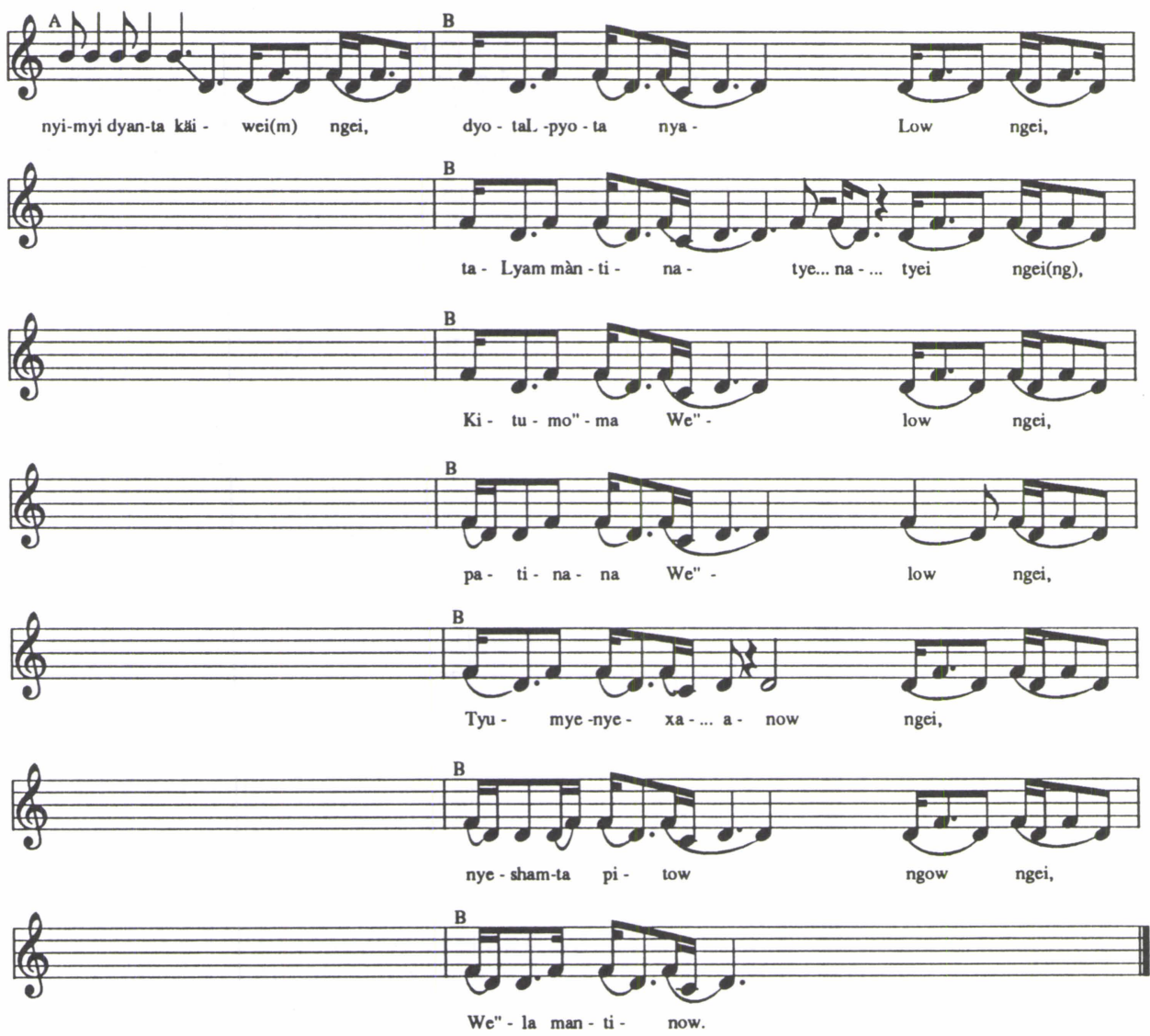

Example 6. We"la Lyechamang sho. Performed by Polina Gelevna Turutina (née Pya'k), Tarko-Sale 1990. Recording, transcription of the text, translation into Russian and commentary by Inna Antonovna Wello. Further transcription, translation into English and transcription of the singing by J. Niemi.

We"la mantinyiwei ngei

Lyechama We"lowLow ngei, nyimyi ka... nyimyi dyanta käiwei(m) ngei dyotaLpyota nyaLow ngei taLyam màntinatye... na...tyei ngei(ng) Kitumo"ma We"low ngei
I am (from) We"la (family) speaking,

Lyechama We"la,

I am very much

delighted,

that

my son, Kitumo"ma We"la, 
patinana We"low ngei

Tyumyenyexa... anow ngei nyeshamta pitow ngow ngei We"la mantinow... continues We"la's work.

In Tyumen' (there are lots of other roads), but he chose my way, It is We"la speaking...

\subsubsection{Ngatsyeki syo / nyukubts}

A syo can be that of a baby too. In this case it is called a ngatsyeki syo 'children-song', a 'cradle song' or a nyukubts, a 'fondling song' (nyukuts 'to fondle'; nyukubs; Nenyang $1985,5)$. It is the personal song of a newborn baby and a child, composed by her mother or a close relative.

The parents reflect their future hopes for the child in a ngatsyeki syo. It serves as the personal song of the child, until he/she can compose an own song. The Taimyr Nganasan consider it as an amulet, that protects the child. (cf. Bogdanov 1982)

Some of the ngatsyeki syo are primarily structured by rhythm, while the melody may have an intonation close to tonal and rhythmical speech, rather than differentiated musical tones.

This is the case with the following nyukub(t)s of the most Eastern Nenets living in the mouth of Yenisei and on the west coast of the Taimyr Peninsula. The playful intonation, at times close to rhytmic and tonal speech, makes these kind of songs quite difficult to transcribe to the Western notation:

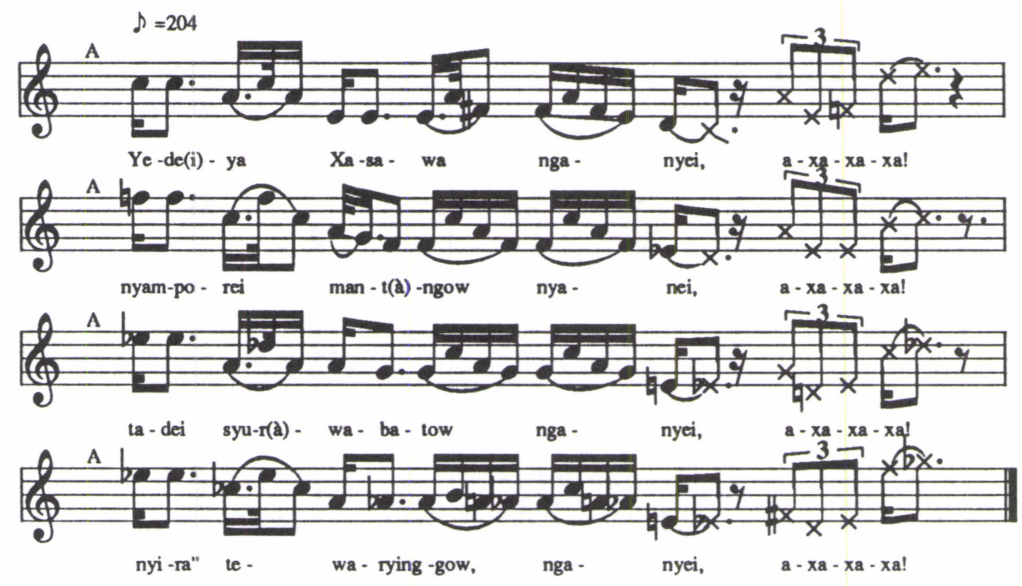

Example 7. Nenyang" Yedei' Xasawa nyukubs. Performance, recording, transcription of the text, translation into Russian and commentary by Lyubov' Prokop'evna Nenyang, Dudinka 1995. Further transcription, translation into English and transcription of the singing by J. Niemi.

Yede(i)ya Xasawa nganyei, axaxaxa! nyamporei mant(à)ngow nyanei, axaxaxa! tadei syur(à)wabatow nganyei, axaxaxa! nyira" tewaryingow, nganyei, axaxaxa!
Yedei Hasawa, ahahaha!

A very fast, hard-working little man, ahahaha! If he runs away, ahahaha!

It is difficult to catch him, ahahaha! 


\subsection{The shamanistic songs}

The traditional worldview of the Nenets is animistic; the environment is believed to be informed by a hierachy of different spirits, the paramount being Num', a major deity of the heaven. The mediator between the ordinary world and the upper- and underworlds of the spirits is tádyebya, a Nenets shaman. The Nenets tádyebyas are ranked according to their spiritual attachment and function and according to their experience (see further: Khomich 1981).

The songs directly connected with the shamanistic ritual, can be divided into two subtypes. To the first subtype belong the "magic songs" proper, that the Nenets shaman $^{11}$, tádyebya, performs during his séance. To the second subtype belong the shamanistic narrative songs, which contain stories about the shamans and mythological entities (cf. Helimski 1989, 26) ${ }^{12}$.

Lehtisalo $(1922,89)$ defines the shamanistic songs as "songs sung with the accompaniment of the witch drum and having the content related to the mythical beliefs, where the journeys of the Samoyeds to the spirits or to the deceased are depicted".

These songs are referred to with a general, but somewhat obscure appellation sámbadabts ${ }^{13}$. This name is closely related to one of the functional categories of Nenets shamans, the sámbana. The sámbana shamans were specialized only in escorting the dead to the world of the dead and to the ritual cleaning and protection of the relatives, their dwelling and equipment (cf. Khomich 1981, 16). Lehtisalo $(1956,187)$ proposes a Forest Nenets song type name tachyipyat"ma kinawsh, that is formed out of the general appellation of the shaman, tádyebya, and of the song type, xinabts.

Furthermore, Khomich $(1981,16)$ assumes the category of the sàmbana-shamans to be of relatively late origin: "...the duties of a shaman specialized in the funeral rites (i.e. sámbana) were not considered as indispensable, and besides, there is no information about this kind of shamans in the 18th century sources."

Interestingly, Kupriyanova gives practically no information about the shamanistic songs. She has assigned the shamanistic songs to the category of the shamanistic fairy tales in her typology of the Nenets oral tradition (Kupriyanova 1960,17). She only states briefly, that "the shamanism had a once certain role in the folk practices and therefore it has been possible to record a corpus of shamanistic songs and tales". (Kupriyanova 1960, 19). Also later she makes only a passing reference to the existence of Lehtisalo's material (cf. Kupriyanova 1965, 20). This is interesting in that she gives much more extensive information about all the other categories of the Nenets songs. This may be partially due to the places she recorded her material, namely among the Malaya Zemlya tundra (actually only the village of Nel'min-Nos at the delta of the

\footnotetext{
${ }^{11}$ The word «shaman" has spread to international use - via Russian - originally from the Evenki language. The Turkic word "kam» could also have spread elsewhere, but for some reason it didn't, but was left in Russian in "kamlaniye» 'a shamanistic séance'.

${ }^{12}$ Castrén has labelled one song as "tádieibtso" (Castrén-Lehtisalo 1940,150) and described it as «an epic song with a shaman theme». Simoncsics has also a mention of these songs (tádebtso) $(1978,401)$. However, none of the Nenets that I have asked about the existence of a shaman song tádebtso, has recognized such a term. Probably the "tádieibtso/tádebtso" refers to something like «tádyebya' syo» 'shaman's song', pronounced as atádyebyansyo». Lehtisalo reports of a word tadebtsu as 'the helping spirits of the shaman' $(1956,478)$.

${ }^{13}$ Lehtisalo has also translated the corresponding verb through the concept of the sámbana tádyebya (1956, 406): "sámpá 'to escort the shadow-souls of the dead to the underworld with songs and accompaniment of the magic drum'».
} 
Pechora river), having no informants at hand, who would have been able to give information about the Nenets shamanistic practices. More likely, however, is, that at those times discussion of the subject of shamanism was very strictly banned. Thus it is likely, that both the Nenets and Kupriyanova practiced a strong self-censorship with the issue of shamanism.

\subsubsection{Sámbadabts}

In any event, the word sámbadats refers to the general category of Nenets shamanistic songs. The sámbadabts were performed by the shaman during the act of a shamanistic séance and they contained expressions about deities and helping spirits of the shaman (cf. Helimski 1989, 25). The shaman also described his journey in the supernatural world in the song.

Simoncsics $(1978,400)$ has made an interesting analysis of the oldest documented text of a Nenets shaman song. The text was recorded by M.A.Castrén among the Western Nenets in the village of Sëmzha in 1842 (Castrén-Lehtisalo 1940, 302). A shamanistic journey is described in it in the course of the depiction of a shaman. The different phases of the journey are described in detail, while the shaman proceeds through the seven spheres of the sky. The spheral scenery and topography are supernatural and strange. The ultimate goal of the journey is the yesya mya" 'iron hut', the dwelling of the paramount god of the skies, the Num'. Here the shaman acquires the information, that was the objective of the séance. On the return journey, nothing is same anymore, the fantastic topography has been transformed. (cf. Simoncsics 1978, 400)

Lehtisalo speaks about "witch songs» e.g. thus $(1922,97)$ : «If the singer may be exalted already by singing fable songs, raises his exaltation in witch songs to great primordial force. Surely the wizard has to "ensavage", strengthen himself in order to present himself favourably to the elfs and to make his will known. In important places knocks he his head with the drum-stick and may raise up from his seat...in the back of the dwelling to take some dance steps... Every wizard knows a group of these songs, and chooses a song appropriate to the situation."

Simoncsics maintains that these kind of sámbadabtses differ from the more narrative shamanistic songs, especially on the level of their semantic structures, and that they relate to the semantic isomorphism of the "lyric" songs. According to his interpretation, the shaman tries to express something, that has no conceptual or linguistic form; that is "the great mystery of shamanism"..., which is ultimately "the interdependence, the secret connection of life and death". (Simoncsics 1978, 401)

The following is a fragment of Forest Nenets shaman song. The recording has been made for the radio of the Yamal Nenets autonomous district and recorded outside the ritual, however.

The text line is octosyllabic, but Ngewasheta places lots of supplementary syllables between the text syllables proper. In this example is heard only the initial (octosyllabic) text line of the incantation, following a short introductory line, consisting of supplementary syllables. In the transcription a text line encompasses a whole line in the score. The inner structure of the lines is shown with the broken lines. They divide the melodic line into four parts, in the beginning of which are the places for the meaningful syllables (underlined). This shaman song is very illustrative in pointing out the big amount of supplementary syllables in a text line. 


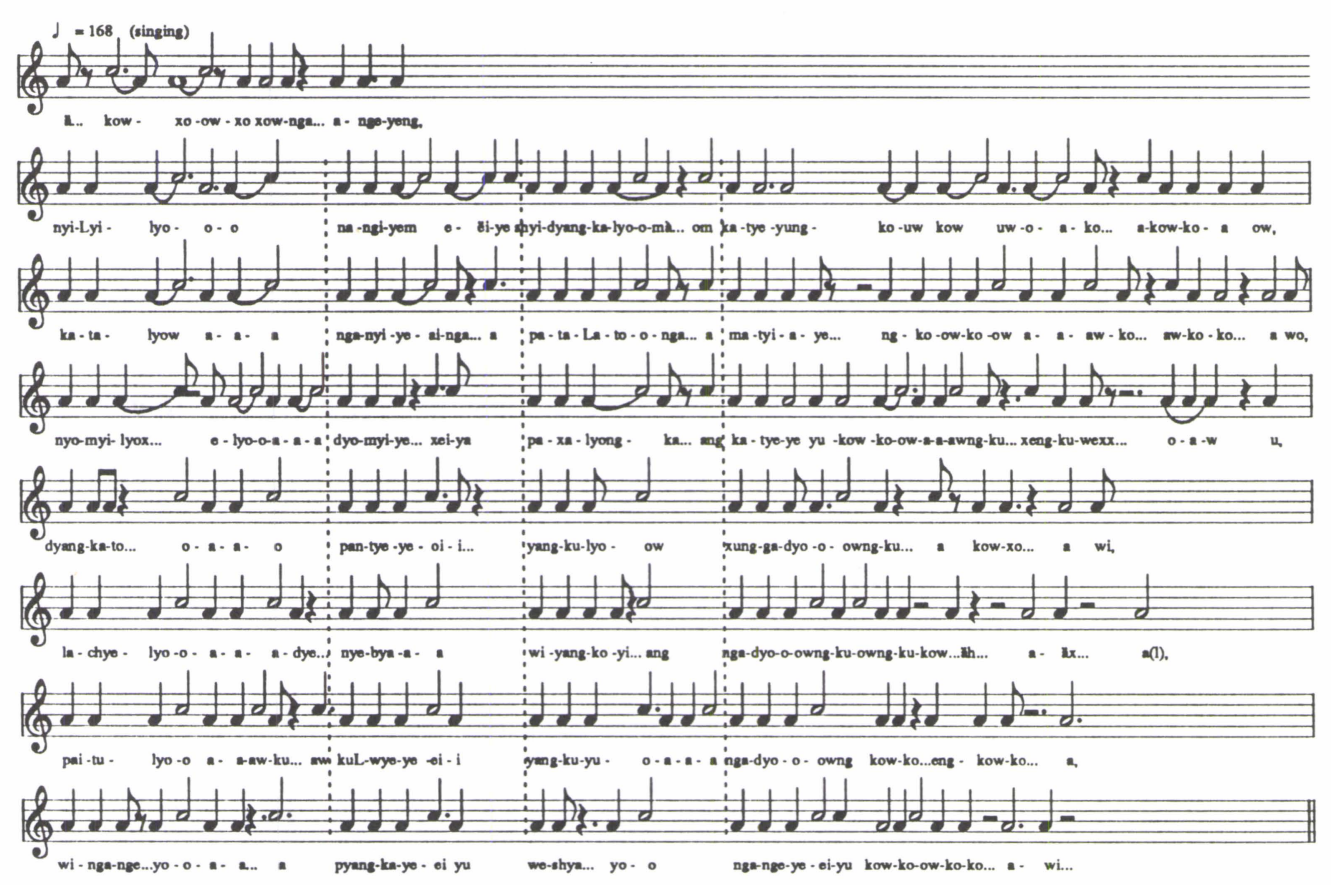

(Continuation as nine lines of similar type.)

Example 8. "An old drum". A sung incantation that is related to a shaman song called She"wyi kingnya'ta pyenshaL "The seven-ways-sounding drum". Performed by Okhol' Ngewasheta. Recorded by Yamal Nenets Autonomous District Radio (archive nr. Ya-204/3). (A recording probably from 1980's.). Transcription and translation (into Russian) of the text variant of this song by I. A. Wello. Unchecked transcription of the text, its translation into English and transcription of the singing by J. Niemi.

\section{(Approximate translation)}

nyilyinangy shyidyangkat(à) Not for foolish merry-making (did my underworld grandmother spirit equip me with a drum)

Due to the extreme rarity of examples of genuine Nenets shaman songs and even other octosyllabic songs, only some fundamentals of their metric construction can be outlined. First, as can be seen from the example of Ngewasheta, the meaningful syllables of a text line are scattered among and between the multitude of supplementary, synsemantic syllables. Second, the octosyllabic line can consist of two four-syllable parts, each of which have a default final supplementary syllable. Examining the available shamanistic and octosyllabic songs, some basic types of formation of a text line can be discerned.

1) As in the song of Ngewasheta, an octosyllabic text line is formed by certain succession and combination of proper text syllables "S1-8" and supplementary syllables or syllable groups "(S)". In this song their scheme is of the form of

$$
\mathrm{S} 1+\mathrm{S} 2+(\mathrm{S})+\mathrm{S} 3+\mathrm{S} 4+(\mathrm{S})+\quad \mathrm{S} 5+\mathrm{S} 6+(\mathrm{S})+\mathrm{S} 7+\mathrm{S} 8+(\mathrm{S}),
$$


with some exceptions, probably due to the highly expressive style of performance. Especially the final position (S) contains a group of supplementary syllables (how, kow, ow).

Another example of this type is a sung fairy tale reminding a shamanistic song (sambadabsraxa laxanako), sung by Paraskov'ya Nikolaevna Maryueva in Nel'min-Nos, 1994. It has a simple succession scheme of

$$
\mathrm{S} 1+\mathrm{S} 2+\mathrm{S} 3+\mathrm{S} 4+(\mathrm{S})+\mathrm{S} 5+\mathrm{S} 6+\mathrm{S} 7+\mathrm{S} 8+(\mathrm{S}) .
$$

The analysis of the text lines in this song points to the firm existence of a caesura in an octosyllabic text line, and in this example the crossing of the caesura is marginal, which means, that the major word border groups in this song (and in other songs as well) are paired (SSSS+SSSS, SS+SS+SSSS, SSSS+SS+SS, SS+SS+SS+SS). Especially here, in Maryuyeva's song, the predominance of the SSSS+SSSS-type is obvious (36.6\% of all the lines). The majority of the text lines (63.4\%) represent the "full" 8-syllable line, while the rest are "incomplete", where either the 6th (23.9\%) or 2nd $(4.2 \%)$ syllable is missing. There are clear traces of hexasyllabic lines among these incomplete lines. The rest of the lines are half lines, mostly sung by mistake (8.5\%). 

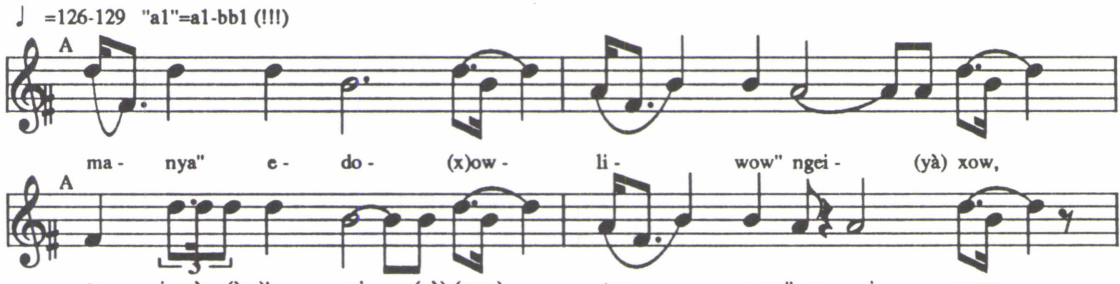

te yi-nyà-m(àm)' pe- rei - (yà)-(xow) - tya - wow" nge... ei wow,

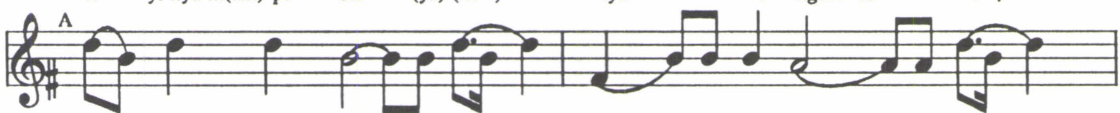

Sying - ga nya- rei- (yà)-xow pe- r(a)-nga-nyow - (a) kow,

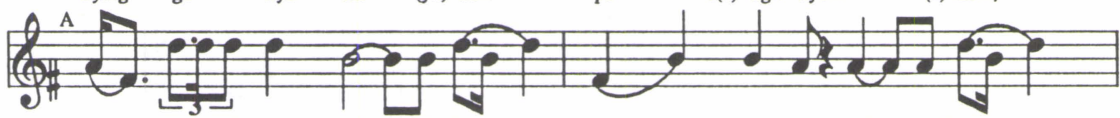

te yi-nyà-m(àm)' pe - rei - (yà)-(xow) - nga - nyow nge... ei - (yà) xow,
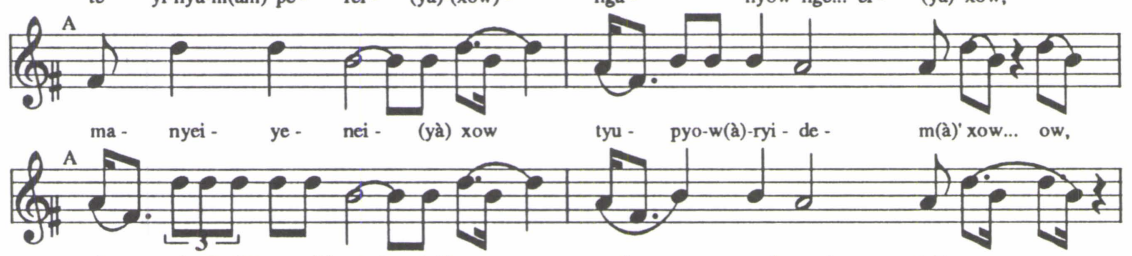

A yi-ryi-n(a) ma-r(a) -tsyei - (yà) xow nyi - nyà - ngei - $\quad$ (yà) xow...,

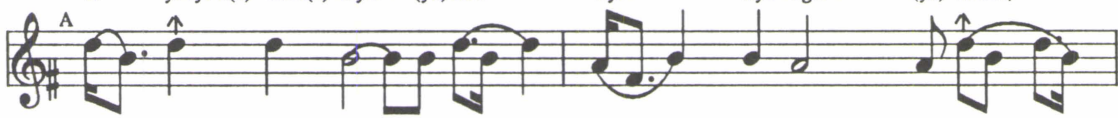

le - mo- re - tsyow (a) - xow nge - sye - yei - (yà) xow,

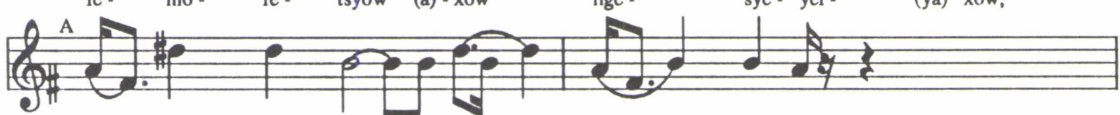

ma- nyei ye - nei - (yà) tyu - pyow - ri - dem nge...

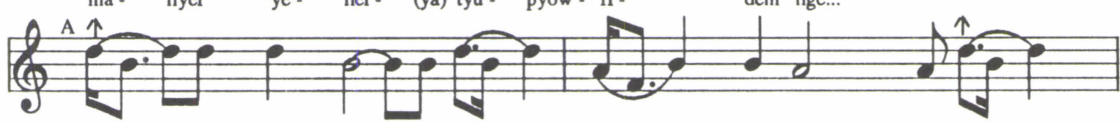

nye - $\quad r(a)$ - ngè - now - (à)" xow nya - now - ngei - (yà) xow,
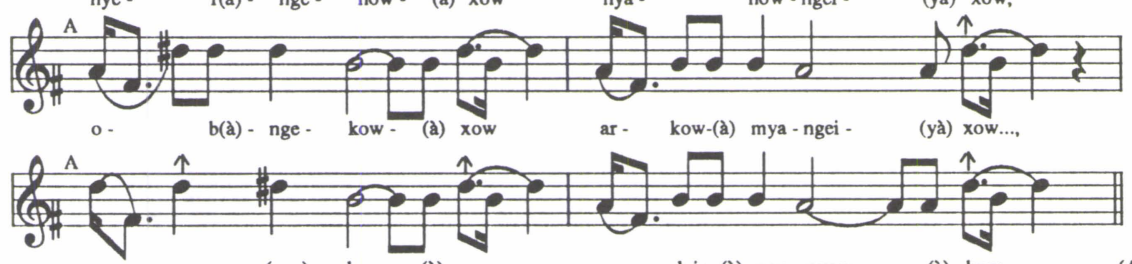

mya - nge - (nge) - kow - (a) xow nga- dyiw-(a) mya-nyow - (a) kow,

Example 9. Sambadabsraxa laxanako (A fairy-tale reminding sámbadabs). Performed by Paraskov'ya Nikolaevna Maryueva (née Taibarei). Recorded by J. Niemi, Nel'min-Nos, 11.8.1994. Transcription and translation (into Russian) of the text by A. T. Lapsui. Further transcription of the text, its translation into English and transcription of the singing by J. Niemi.

It has to be noted also, that there is no need to organize the melodic rhythm according to the word-border and accentuation, like in hexasyllabic songs. Therefore there is only one word-border type in the octosyllabic songs, resulting as uniformity in the melodic 
rhythm and in the location of the sung syllables. Maryuyeva's song is representative of this also, as a rare case of a long (71 lines) performance of a song in the octosyllabic meter. The sung syllables concentrate quite uniformly to the 4th and 8th syllabic position, but they can occur also in the 6th position.

The strict organization of this type of an octosyllabic line in some of the shamanistic songs led, for example, Lehtisalo to organize his text transcriptions into columns of four syllable lines $(1947,469-546)$. It is especially interesting to refer here to this kind of shaman song (Lehtisalo 1947, 469), which has been possible to identify with the corresponding phonogram (Ph. 26a-b) (see: Niemi \& Lapsui 1995, 147-148). The line scheme of the phonogram here, however, does not even suggest the presence of a two part octosyllabism:

$$
(\mathrm{S})+\mathrm{S} 1+\mathrm{S} 2+\mathrm{S} 3+\mathrm{S} 4+\mathrm{S} 5+\mathrm{S} 6+\mathrm{S} 7+\mathrm{S} 8 \text {. }
$$

2) The similar line structure can be echoed, meaning that some of the proper text syllables may be repeated according to a certain scheme. Examples of this type can be found from the songs recorded by Lehtisalo in 1911 (see: Niemi \& Lapsui 1995, 154; 161). The succession scheme in the example 11. (Ph. 32a) can be discerned as

$$
\mathrm{S} 1+\mathrm{S} 2+\mathrm{S} 3+\mathrm{S} 4+\mathrm{S} 5+\mathrm{S} 6+\mathrm{S} 7+\mathrm{S} 8+\mathrm{S} 5+\mathrm{S} 6+\mathrm{S} 7+\mathrm{S} 8+(\mathrm{S}),
$$

although because of the bad quality of the recording, it was not possible to transcribe all the words of the song.

The second shamanistic song in the same phonogram (example 26. (Ph.32b)) contains another principle of repetition. It is interesting to notice, that there are alternating schemes in this song. After S1 and S2 there is a place for the optional (S), and after that follows the rest of the text line S3-8. After that follows either echoed S5 and S6, or (S). The line scheme ends with echoed S7 and S8 followed by yet a final (S):

$$
\begin{array}{lll}
\mathrm{S} 1+\mathrm{S} 2+(\mathrm{S}) & +\mathrm{S} 3+\mathrm{S} 4+\mathrm{S} 5+\mathrm{S} 6+\mathrm{S} 7+\mathrm{S} 8+\mathrm{S} 5+\mathrm{S} 6+\mathrm{S} 7+\mathrm{S} 8+(\mathrm{S}), \\
\mathrm{S} 1+\mathrm{S} 2+ & \mathrm{S} 3+\mathrm{S} 4+\mathrm{S} 5+\mathrm{S} 6+\mathrm{S} 7+\mathrm{S} 8+\mathrm{S} 5+\mathrm{S} 6+\mathrm{S} 7+\mathrm{S} 8+(\mathrm{S}), \\
\mathrm{S} 1+\mathrm{S} 2+(\mathrm{S})+\mathrm{S} 3+\mathrm{S} 4+\mathrm{S} 5+\mathrm{S} 6+\mathrm{S} 7+\mathrm{S} 8+(\mathrm{S})+ & \mathrm{S} 7+\mathrm{S} 8+(\mathrm{S}), \\
\mathrm{S} 1+\mathrm{S} 2+ & \mathrm{S} 3+\mathrm{S} 4+\mathrm{S} 5+\mathrm{S} 6+\mathrm{S} 7+\mathrm{S} 8+(\mathrm{S})+ & \mathrm{S} 7+\mathrm{S} 8+(\mathrm{S}), \\
\mathrm{S} 1+\mathrm{S} 2 & \mathrm{~S} 3+\mathrm{S} 4+\mathrm{S} 5+\mathrm{S} 6+\mathrm{S} 7+\mathrm{S} 8+ & \mathrm{S} 7+\mathrm{S} 8+(\mathrm{S}),
\end{array}
$$

An example of more uniform echoed line scheme can be found from the shaman song performed by Ngabtiko Lapsui (audio example not available). There are two alternating line schemes in this song:

$$
\begin{aligned}
& \mathrm{S} 1+\mathrm{S} 2+\mathrm{S} 3+\mathrm{S} 4+\mathrm{S} 1+\mathrm{S} 2+\mathrm{S} 3+\mathrm{S} 4+\mathrm{S} 5+\mathrm{S} 6+\mathrm{S} 5+\mathrm{S} 6+\mathrm{S} 7+\mathrm{S} 8+(\mathrm{S}) \\
& \mathrm{S} 1+\mathrm{S} 2+\mathrm{S} 3+\mathrm{S} 4+\mathrm{S} 1+\mathrm{S} 2+\mathrm{S} 3+\mathrm{S} 4+\mathrm{S} 7+\mathrm{S} 8+\mathrm{S} 5+\mathrm{S} 6+\mathrm{S} 7+\mathrm{S} 8+(\mathrm{S}) .
\end{aligned}
$$




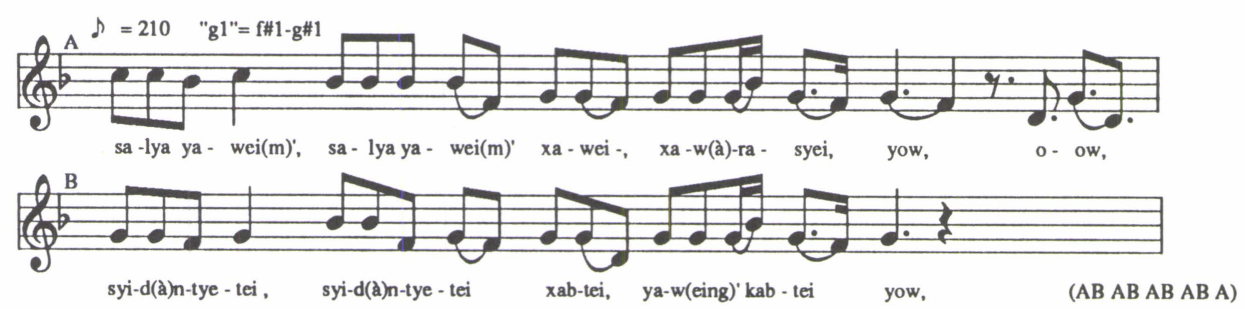

Example 10. Sámbadabs (Shaman's song of Ngabtiko Lapsui). Performed by Valentina Ngabtikovna Salinder. Recorded by Elena Timofeevna Pushkarëva, Nyda 1993. Transcription and translation (into Russian) of the text by E. T. Pushkarëva. Further transcription of the text, its translation into English and transcription of the singing by J. Niemi.

It is worth noticing here, that the echoed syllables can also be a part of a word and furthermore, they can be a part from the end of the word also.

Helimski $(1988,72-74)$ has an interesting notion of similar principles in the formation of a text line with the material of the allegoric keingeirsya-songs of the Nganasan. Although the keingeirsyas conform to the general rules of the hexasyllabismus of the Northern Samoyed, the principles of echoing and repeating of syllables in a text line, as well as the principles of reorganization of their succession are strikingly similar. It has to be emphasized, however, that there is no such a thing in Nenets hexasyllabic text lines.

\subsection{The modern Nenets songs}

By "modern" Nenets songs I mean here composed, arranged music, transformed by synchronisation with European musical forms. To date, the first and the only Nenets composer - with a recognised status - of Nenets songs is Semën Nyarui. His songs have become quite popular among the Nenets (especially those living sedentarily in the regional multiethnic centers). For example, the 18-20 years old generation of Nenets students of the Herzen University in St.Petersburg know most likely only Nyarui's songs, if anything. But then the majority of those students have come from multiethnic environment, in some cases with rapidly deteriorating command of Nenets language.

The Yamal-born Nyarui ranks today with the elite of Nenets national and cultural characters together with Nenets writers, poets and singers (e.g., Tiko Wilko, Ivan Yuganpelik, Leonid Laptsui, Prokopii Yawtysyi, Anna Nerkagi, Elena Susoi and Gennadii Puiko). He has a background of institutional training (St. Petersburg State Conservatory).

Some of the fundamentals and conventions of the Nenets song structures converge in Nyarui's songs, above all the anhemitonic scales. He arranges and composes them in order to accommodate the diatonic tonality. He himself has no hesitation in judging the borderline between Nenets and non-Nenets melodic elements (Nyarui 1991).

The following example represents Nyarui's music: harmonized melodies with anhemitonic elements. These transcriptions include some introductory passages for the accompanying piano. They reflect the energetic playing style of Nyarui: an inclination to forte, clanging, resounding melodic fills and syncopation: 

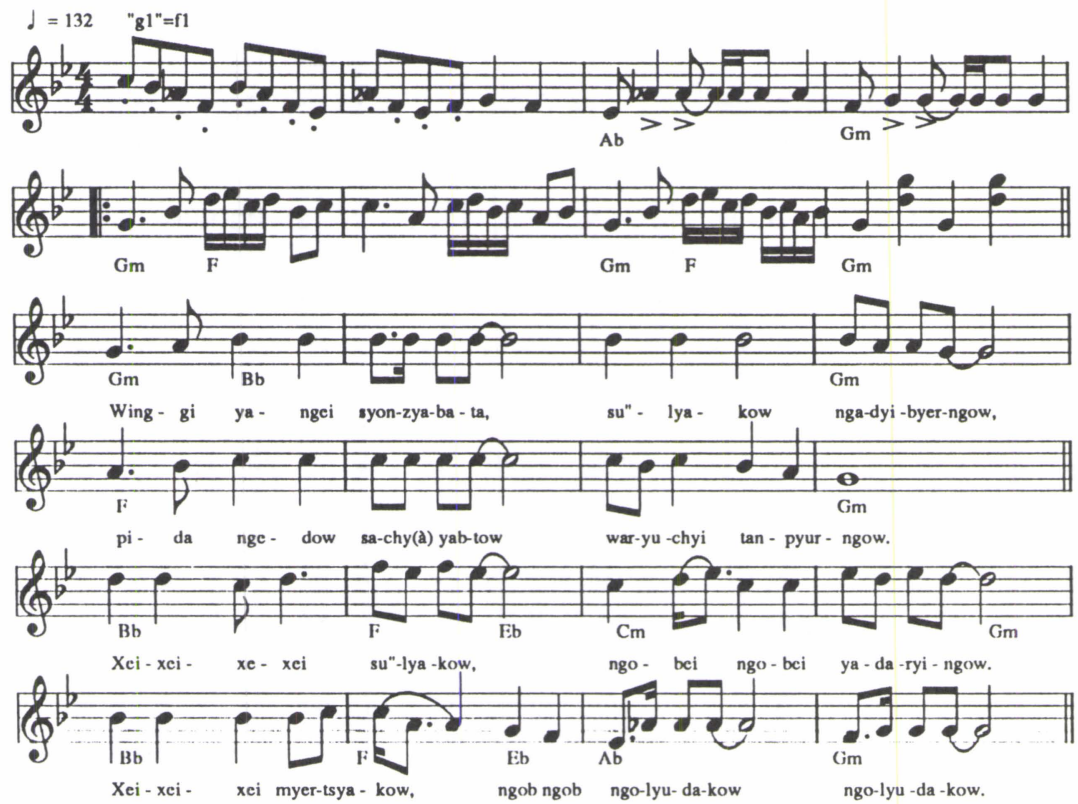

Example 11. "Su"lyako - The reindeer calf» by CSemën Nyarui. Performed by Semën Nyarui (vocal \& piano), Salekhard 1991. Recorded by J. Niemi. Transcription of the text by Maria Yakovlevna Barmich. Further transcription of the text and transcription of the music by J. Niemi.

(1. stanza)

Winggi yangei syonzyabata, su"lyakow ngadyibyerngow, pida ngedow sachy(à) yabtow, waryuchyi tanpyurngow,

Xei xei xe-xei su"lyakow, ngobei ngobei yadaryingow, xei xei xei myertsyakow,

ngob ngob ngolyudakow, ngolyudakow. (approximate content of the text)

"The tundra land is joyful, when the reindeer calf appears there, running and jumping around..."

\section{The musical style of the Nenets as part of the musical style of the arctic}

Regarding its fundamental structural features, the musical culture of the Nenets belongs to the cultural area of the Arctic and Subarctic hunters, fishers and the historically later period of reindeer pastoralists. This cultural area geographically encompasses the whole circumpolar zone from the Sami of Northern Scandinavia through native Siberia to the native people of Arctic/Subarctic Northern America and Greenland.

In terms of cultural ecology, in this zone there are also many fundamental similarities in the subsistence patterns, social organization and relation to the natural and 
supernatural world, and therefore it may be not surprising to find also some basic elements in common in their musical cultures. On the other hand, particularly at the level of these fundamental features, there are similarities also to music cultures outside the native Circumpolar regions, as in the rest of the native American continent, Southern Asia and Australia.

It must be said however that the monumental global statistical style analysis of vocal music, the so called "Cantometrics"-workgroup of Alan Lomax found these kinds of style fundamentals. Lomax defined Siberia as a style area of its own, with a direct counterpart only at the native Tierra del Fuego, Southern America. The native American singing styles he connected to a large "Circumpacific" area (including native Australia), while he interpreted Africa as a large style area of its own, having the "Protomelanesian" (i.e. native Southern Asian) area as its closest counterpart. (see Lomax 1976, 32-33)

The purpose of the comparative statistical analysis of the Cantometricians was to point to the statistical correlations between different singing styles, especially with the additional purpose of utilizing the various test types also pedagogically. It is clear, that this kind of comparison works only at the most fundamental levels, and it may result in truisms difficult to apply further in ethnomusicological research. It must be acknowledged, however, that the Cantometrics experiment is at its most inspiring as pedagogical vehicle.

However, even a little more investigation of a musical style area quickly discloses the infinite variation of the details in a music culture. In this context it is not very useful or precise to state that the Nenets songs belong to the Siberian vocal style area... On the other hand, the material that Lomax had access to was limited only to the historical recording collection of the Ethnographic Institute of the Science Academy of Russia, which was often in lamentably poor physical condition, and represented only a minimal and quite randomly collected part of the native Siberian music cultures.

\subsection{The fundamentals of the music style of the Nenets}

The following outlines some of the main parameters through which it is possible to define further the special features of the Nenets singing style. All these dimensions concern mainly the traditional style, which is undergoing changes connected with the processes of westernization and folklorization, and also, connected to these, revitalization.

\section{1) Vocality}

The Nenets musical style is based on singing, the human voice. The musical instruments, like instant aerophones or idiophones, are marginal, and they are not used to accompany singing. This is also the case with the shaman drum (pyenzyer'), which was used as a ritual instrument, functioning as a symbolic medium in the ritual and an instrumental aid in the shaman's trance technique, and not at all as an accompanying rhythmic instrument. However, nowadays, as a result of revitalization and folklorization of the musical traditions, newly made drums are sometimes used in stage performances as rhythmic instruments.

\section{2) Solo singing}

The singing is individual solo singing. There are no musically coordinated group performances. There are some mentions and interpretations of audience participation 
in the ritual singing (cf. Gáldi 1978, 132, commented in Niemi 1995, 145), but they are of quite dubious reliability or they are not strictly connected to the Nenets.

\section{3) Tonal substance}

The ranges of the melodies are narrow, consisting usually of few tones. Occasionally, however, the borderlines of the melodic segments can be emphasized with interval leaps exceeding the average tonal range of the song. The big interval leaps are more common in the regional styles of the Western Nenets.

First, the interval organization can be described as anhemitonic. This definition does not, however, fully reflect the expressive and tonally transforming musical performance and intonation. And in addition to that, there are numerous melodies, the few tones of which undulate constantly in the interval range of about a whole-step.

Second, they can be described as oligotonic (see: Aizensthadt \& Sheikin (1990, 90) citing $\mathrm{Kvitka}^{14}$ ), to emphasize the minimal number (1-4) of the tones in a melody and their small interval distances. This is also not a comprehensive way of characterizing the tonal system, because of the aforementioned interval leaps.

Third, the interval organization can be described as khazmatonic (cf. Wiora 1956, 195), if emphasizing the predominance of the few leaping intervals in a melody. However, the size of the intervals tends to change during the performance: because of the solistic, unaccompanied and uncoordinated nature of the songs, the interval structures can be processual: the exact size of the intervals in similar places in a melodic curve may change notably during the performance. Therefore the tonal structure in the Nenets songs can be desribed as processual anhemitonic, with oligotonic and khazmatonic features.

The melodic line is essentially undulating and horizontal, which means that it is quite common for the melody to circulate around the fundamental tone during the whole performance. True, in longer performances, the pitch of the fundamental tone tends to rise notably, which eventually results in breaks in the singing and a start of the new melodic passage from lower level. As such, this kind of melodic type is quite common in the Arctic, and especially in the Western Siberia, compared, for example, to the Southwest Siberian Turkic regions, where the melodic movement is descending.

As an illustrative example of this, the Selkup Samoyeds have a variety of singing styles, owing to their being scattered among different areas of the Western Siberian river systems. In the North, along the river Taz, the melodic movement tends to be undulating-horizontal, whereas in South, at the rivers Tym and Ket, the melodic movement is clearly descending (in the range of an octave). (cf. Niemi 1994, 115-116)

\section{4) The existence of the pulse}

The stress pattern of the syllables in a text line has perhaps a more important effect on the melodic rhythm, than any other factor in rhythmic coordination. This and the soloistic, unaccompanied character of performance result in highly processual and varying melodic rhythm. However, it is not correct to consider the melody as unmetric, because of the principles of isometric structures in the text and melodic lines. Furthermore because the isometric lines tend to iterate from the beginning of a song to its end, also the rhythmic shape of the melodic lines tend to be of the same type.

The durations of the pitches are thus highly proportional, so that for example interpreting the durations as fixed combinations (with time signatures in transcription)

\footnotetext{
${ }^{14}$ Kvitka, K. V.: Izbrannye trudy (v 2 t.; 1. t.). Moskva 1971.
} 
adds very little to the analysis, because it suggests the existence of an underlying even pulse in the melody. Ultimately, it would be most effective to describe a rhythm of a melodic line through the opposition of durational proportions, i.e. with short and long durations. This idea is already presented and applied by Lippus in her monography $(1995,28)$, an important study for insights of the structural features in non-European and especially native music.

As regards this presentation, however, there are some regularities in the rhythmic manifestations in some of the Nenets songs, that have tempted me to apply - although somewhat contradictorily - a bit more detailed rhythmic interpretation, in order to see, whether there are some more subtle manifestations of rhythmic proportions.

\section{5) The basic structure of the songs}

The most important structural principle in the Nenets songs is that the text and melodic lines are isometric. The fixed, either hexa- or octosyllabic metre defines the range of the melodic line also, and all the lines in most of the songs are structurally identical with each other. It must be stated, however, that the manifestation of a text line can be very complex, because of the various prosodic means to produce sung language from spoken language (in more detail, see Niemi 1997b).

For such reasons, the Nenets song text structures remained somewhat unclear to the linguists until the end of 1980's, when a Russian linguist Eugene Helimski published his innovative articles about the constancy of the hexa- and octosyllabic structures in Nenets song texts $(1988,1989)$. Some of the former researchers had already implied these kind of structures (Lotz 1954, Hajdú 1978), but Helimski indicated the invariability of these for the first time. The difference was that Helimski examined for the first time the deep levels of the syllabic structures. His further hypothesis was that the hexasyllabic line prevails in every song type, except in shamanistic songs, which tend to have a norm of octosyllabic text line. Thus it seems that there is a sharp division between shamanistic songs and other songs not only on musical, but especially on the textual level.

Usually there are two different melodic lines (sometimes only one, more seldom three or four). If there are two melodic lines, they tend to be grouped regularly, as for example $\mathrm{AB} \mathrm{AB} \mathrm{AB} . . ; \mathrm{AAB} \mathrm{AAB} \mathrm{AAB} . .$. etc.

Thus, the verse form text is the fundamental for its transformation into a song. The word stress in Nenets is the most important factor determining the melody rhythm in a song (see: Niemi 1997, 205). While the word stress falls quite predictably on the initial syllable (or first syllable of any lexical segment of two syllables), it tends to produce some fundamental manifestations in the melody rhythm. As already mentioned (Niemi 1997a 205; 1997b XXX), the hexasyllabic text line structures are predominated by two fundamental syllabic groups, resulting in words containing different amount of syllables. The first can be called as a category of syllable groups organized on the principle of even amount of word-forming syllables (for example SS+SSSS, SS+SS+SS, SSSSSS or SSSS+SS). The second is a category of syllable groups organized on the principle of uneven amount of word-forming syllables (SSS+SSS and its derivatives). When this notion is combined with the stress pattern of the language, its manifestations in a melody rhythm and the principle of isometricity, it can be concluded, that these word-border categories tend to produce their own manifestations in the melodic rhythm.

The differences in the melodic rhythm (and also positions of the syllables) are manifested thorugh the predictability of the stress patterns between the spoken and sung language. The stressed syllables of the spoken language tend to remain un- 
changed while transformed into the sung language and the unstressed syllables of the spoken language tend to change into specific sung syllables in the process of their transformation into the sung language. The transformation of the unstressed syllables in the sung language increases their metric importance: they become more emphasized and some of them are located in the crucial final segments in the melodic line. Schematized, this situation can be compared followingly.

1) Stressed syllables "S" of the spoken language in the main types of the six-syllable strings (text lines):

$$
\begin{aligned}
& S+S+S+S+(S)+S \\
& S+S+S+S+S
\end{aligned}
$$

2) Stressed syllables "S" of the sung language in the main types of the six-syllable strings (text lines):

$$
\begin{array}{r}
S+S+S+(S)+S+S \\
S+S+S+S+S
\end{array}
$$

3) Result, when these syllabic positions are synchronized according to their rhythm, given that the stressed syllables of the sung language have to coincide in the isometric framework:

$$
\begin{aligned}
& S+S+(S)+S+S \\
& S+S+S \\
& S+S+S+F S S)
\end{aligned}
$$

The main point here is, that there has to be some kind of rhythmic synchronization, when text lines belonging to the different word-border categories appear in a song and its rhythmic scheme. This happens quite often by densification of the time values of the SSS+SSS text line so, that the first stressed sung syllable coincides with the SS+SSSS text line. In the end of the line, however, the situation is different, due to the amount of the available syllables. It is quite common, that in the SSS+SSS type the final syllable is a (final) supplementary syllable, although not necessarily.

A typical example of this is an individual song performed by Lyubov' Nenyang. The basic metric scheme here (for the SS+SSSS-type) is based on three iambic foot (lines 2.-4. and 6.-8.). However, in the SSS+SSS type the syllables produce a scheme of anapest+iamb+long (line 9.) 

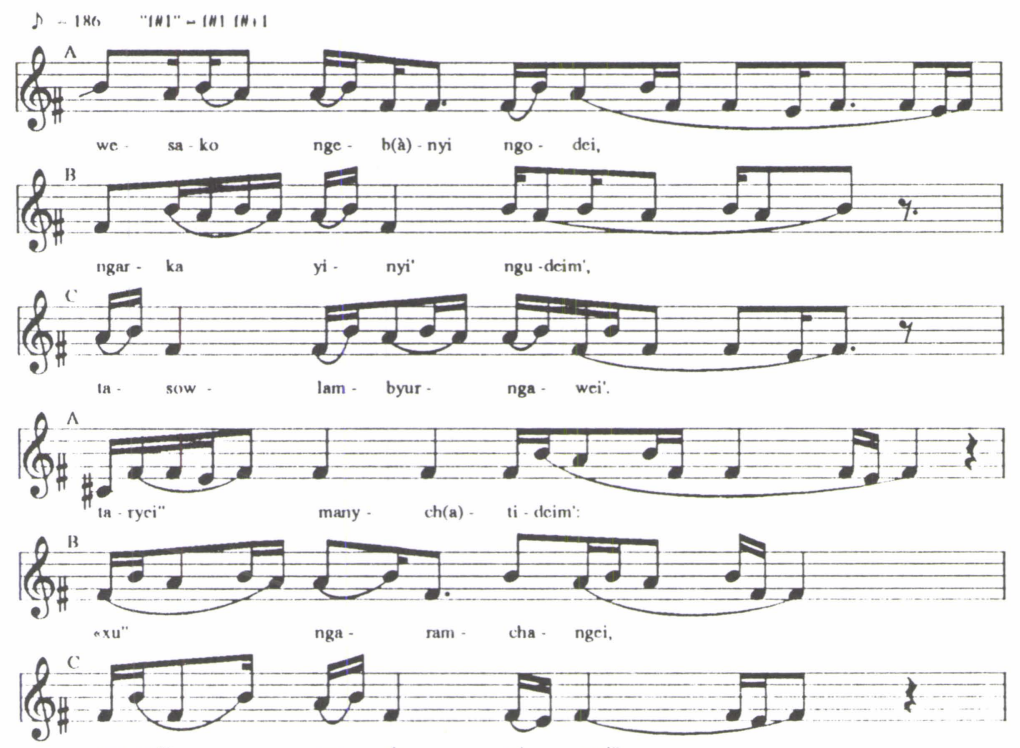

nyu -nyi" wa da - wi - nyei",
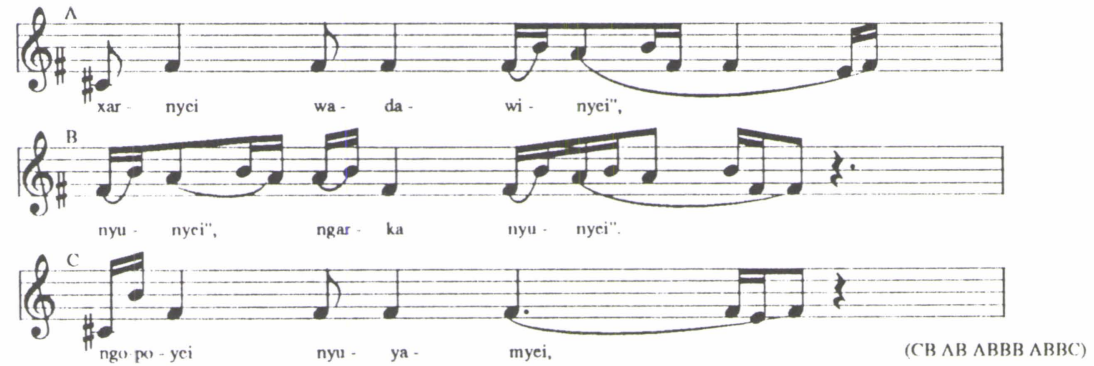

Example 12. Yadko Yadarta yabye' sho. The adult individual song of Y.Y. (Mikhail Antonovich Kayarin). Performance, recording, transcription of the text and its translation into Russian by Lyubov Prokop'evna Nenyang, Dudinka 1995. Transcription of the song, further transcription of the text and its translation into English by J. Niemi.

\section{6) The sound production}

Both the men and women tend to sing with slight laryngalisation, i.e they tend to produce the singing voice in the back of the throat. In individual songs the laryngalization is weaker, almost absent, and in the sung narrations it may be somewhat stronger (especially with men). The internal nature of the personal songs is often reflected in frustratingly reduced pronounciation of the song text. Deciphering the mumbled words of these kind of songs can be sometimes beyond the powers of other Nenets too.

\section{Conclusion}

The traditional songs and the song system, with corresponding social practices, are living most vigorously at the remote frontiers of the Nenets regions: in the North, in 
Yamal, Gydan and to a lesser extent in Kanin and Taimyr peninsulas. The traditional song system exists along with the social and economic practices of the reindeer pastoralists, hunters and fishermen.

More South, the Nenets have had to adapt to stronger interethnic relations, when living in villages together with Russians, Ukrainians, Tartars, Khanty and Komi for example. Usually they all use the Russian language to facilitate communication. The ethnic traditions and the mother tongue withdraw from the polyethnic social life inside the family.

The change in the music culture is reflected in alienating and folklorizing relationship with the traditional Nenets way of life. Thus, the songs become a «tradition», «folk music», an object of cherishing and studying, instead of part of everyday life.

\section{References}

Abrahams, Roger D. 1981. The Complex Relations of Simple Forms, Folklore Genres, ed. Dan Ben-Amos. Austin: University of Texas Press. 193-214.

Anonymous 1990. Yazyki narodov SSSR: Raspredeleniye narodov SSSR po natsional'nosti, rodnomu i vtoromu yazyku (po perepisi 1989 g.), Vypusk 6-y, Soyuz (Entsiklopediya Soyuza) N:o 51/1990.

Ben-Amos, Dan 1981. Introduction, Folklore Genres, ed. Dan Ben-Amos. Austin: University of Texas Press. ix-xlv.

Bogdanov, I. A. 1982. Nganasanskaya muzyka (Melodiya S 30 176514). (Article in the record sleeve.) Moskva: Melodiya.

Bogdanov, I. A. 1988. "Nenetskaya i enetskaya muzyka". (Manuscript for a sleeve article for an unpublished record.)

Castrén M. A. \& Lehtisalo Toivo 1940. Samojedische Volksdichtung, Mémoires de la Société Finno-Ougrienne 83. Helsinki.

Dobrovol'skii, B. M. 1965. O napevakh nenetskikh epicheskikh pesen, Epicheskiye pesni nentsev, ed. Ye. M. Meletinskii. Moskva: Nauka. 757-780.

Dobzhanskaya, O. E. 1995. Pesni nganasan, ed. A. N. Nemtushkin. Krasnoyarsk: Upravleniye kul'tury administratsii Taimyrskogo avtonomnogo okruga.

Dolgikh, B. O. 1970. Ocherki po etnicheskoi istorii nentsev i entsev. Moskva: Nauka.

Dundes, Alan 1980. The Morphology of North American Indian Folktales, FF Communications No. 195. Helsinki: Academia Scientiarum Fennica.

Gáldi, László 1978. On some problems of versification in Samoyed shamanistic songs, Shamanism in Siberia, ed. Mihály Hoppál. Budapest: Akadémiai Kiadó. 125-136.

Gomon, A. A. 1980. O nekotorykh osobennostyakh traditsionnykh nenetskikh improvizatsii, Finno-ugorskii muzykal'nyi fol'klor $i$ vzaimosvyazi s sosednimi kulturami, ed. I. Rüütel. Tallinn: Eesti Raamat. 205-213.

Grachëva, G. N. 1983. Traditsionnoye mirovozzreniye okhotnikov Taimyra XIX nachala XX v. (po materialam nganasan). Moskva: Nauka.

Hajdú, Péter 1978. The Nenets Shaman Song and its Text, Shamanism in Siberia, ed. Mihály Hoppál. Budapest: Akadémiai Kiadó. 355-372.

Helimski, Eugene 1988. Sillabika stiha v nganasanskikh inoskazatelnykh pesnyakh, Muzykal'naya etnografiya Severnoi Azii, ed. Yu. I. Sheikin. Novosibirsk: Nauka. 52-76. 
Helimski, Eugene 1989. Glubinno-fonologicheskii izosillabizm nenetskogo stikha, Journal de la Société Finno-Ougrienne 82. Helsinki. 223-268.

Honko, Lauri 1967. Perinnelajianalyysin tehtävistä, Sananjalka 9. Turku. (Published with slight modifications as: Genre analysis in Folkloristics and Comparative Religion. Temenos Vol. 3. Helsinki 1968.) 125-149.

Honko, Lauri 1995. Multiformit ja pitkän eepoksen arvoitus, Sananjalka 37. Turku. 117-145.

Janhunen, Juha 1990. Ethnic Death and Survival in the Soviet North, paper presented in the conference of the International Association for the History of Religion IAHR -90 in Helsinki, 14.5. 1990.

Katzschmann, Michael \& Pusztay, János 1978, Jenissei-Samojedisches Wörterverzeichnis. Hamburg.

Khomich, L. V. 1966. Nentsy. Moskva-Leningrad: Nauka.

Khomich, L. V. 1976. Problemy etnogeneza i etnicheskoi istorii nentsev. Leningrad: Nauka.

Khomich, L. V. 1981. Shamany u nentsev, Problemy istorii obshchestvennogo soznaniya Sibiri (po materialam vtoroi poloviny XIX - nachala XX v.), ed. I. S. Vdovin. Leningrad: Nauka. 5-41.

Kupriyanova, Z. N. 1960. Nenetskii fol'klor. Leningrad: Nauka.

Kupriyanova, Z. N. 1965. Epicheskiye pesni nentsev. Moskva: Nauka.

Kupriyanova, Z. N. 1973. Epos nentsev, Spetsifika fol'klornykh zhanrov. Moskva. 172-199.

Kuusi, Matti 1963. Kirjoittamattomasta kirjallisuudesta. Suomen kirjallisuus I, ed. Matti Kuusi. Keuruu: SKS. 7-30.

Kuusi, Matti, Bosley, Keith \& Branch, Michael 1977. Finnish Folk Poetry Epic. Suomalaisen Kirjallisuuden seuran julkaisuja 329. Helsinki: SKS.

Labanauskas, K. I. (Ed.) 1992. Fol'klor narodov Taimyra, vyp. 1 (enetskii fol'klor). Dudinka: Taimyrskii okruzhnoi tsentr narodnogo tvorchestva.

Lehtisalo, Toivo 1922. Jurakkisamojedien lauluista, Kalevalaseuran vuosikirja 2. Helsinki. 82-102.

Lehtisalo Toivo 1936-37. Beobachtungen über die Jodler, Journal de la Société Finno-Ougrienne XLVIII. Helsinki. 1-35.

Lehtisalo, Toivo 1947. Juraksamojedisches Volksdichtung, Mémoires de la Société Finno-Ougrienne 90. Helsinki.

Lehtisalo, Toivo 1956. Juraksamojedisches Wörterbuch, Lexica Societatis Fennougricae XIII. Helsinki.

Lippus, Urve 1995. Linear Musical Thinking: A Theory of Musical Thinking and the Runic Song Tradition of Baltic-Finnish People. Tallinn: AS Pakett.

Lomax, Alan 1976. Cantometrics - an approach to the anthropology of music. Berkeley: The University of California.

Lotz, John 1954. Kamassian Verse, Journal of American Folklore Vol. 67, No. 266. 369-377.

Mikushev, A. K. 1987. Komi yözkostsa epos - Komi narodnyi epos, ed. B. P. Kirdan. Moskva: Nauka.

Nenyang, L. P. 1985. Nenetskiye pesni. Krasnoyarsk: Krasnoyarskoe knizhnoe izdatel'stvo.

Niemi, Jarkko 1993. Nenetsien musiikkikulttuuri - laulut ja soittimet. (Lisensiaattitutkimus.) Tampereen yliopisto. (Unprinted.)

Niemi, Jarkko 1994. Kai Donnerin tallentamat selkuppi- ja kamassisamojedilaulut A. O. Väisäsen "Samojedische Melodien"-nuottijulkaisussa, Etnomusikologian 
vuosikirja 6. Helsinki: Suomen etnomusikologinen seura. 103-134.

Niemi, Jarkko 1995. Transcriptions of Nenets Songs in A.O.Väisänen's

"Samojedische Melodien" Re-evaluated, Journal de la Société Finno-Ougrienne 86. Helsinki. 129-166.

Niemi, Jarkko 1997a. Collective Tradition meets Individual Creation: Modern Nenets Songs, Etnomusikologian vuosikirja 9. Jyväskylä: Suomen etnomusikologinen seura. 202-226.

Niemi, Jarkko 1997b. Music Transcriptions in Z. N. Kupriyanova's Collection of Nenets Epic Songs, Journal de la Société Finno-Ougrienne 87. Helsinki. 161224.

Pushkarëva, E. T. 1990. Lichnye pesni nentsev, Sovremennoye finno-ugrovedeniye opyt i problemy, eds. O. M. Fishman, Ye. A. Ryabinin \& I. V. Dubov. Leningrad: Muzei Etnografii narodov SSSR. 81-85.

Salminen, Tapani 1997. Finno-Ugrian Languages. http://www.helsinki.fi/ tasalmin/fu.html.

Simoncsics, Pál 1978. The Structure of a Nenets Magic Chant, Shamanism in Siberia, ed. Mihály Hoppál. Budapest: Akadémiai Kiadó. 394-403.

Tereshchenko, N. M. 1990. Nenetskii epos. Materialy i issledovaniya po samodiiskim yazykam. Leningrad: Nauka.

Wiora, Walther 1956. Älter als die Pentatonik, Studia Memoriae Béla Bartók Sacra, eds. Kodály, Zoltán \& Lajtha, Lájos. Budapest: Akadémiai Kiadó. 185-208.

\section{Interviews}

Barmich, Maria Yakovlevna (1988): 15.11.1988 St.Petersburg. JN.

Laptander, Raisa \& Emel'yan (1991): 24.3.1991 Laborovaya. JN. TYO/KPL 10074. Lapsui, Anastasia Timofeevna (1993): 16.10.1993 Helsinki. JN.

Nyarui, Semën Nikolaevich (1991): 30.3.1991 Salekhard. JN.

Puiko, Gennadii Alekseevich (1991): 4.4.1991 Yar-Sale. JN. TYO/KPL 10082.

Pushkarëva, Elena Timofeevna (1988): 6.1.1988 St. Petersburg. Juha Janhunen.

Pushkarëva, Elena Timofeevna (1992): 29.8.1992 Helsinki. JN.

Tokholya, Galina Odmovna (1991): Discussion, 27.3.1991 Salekhard. JN. 